\title{
LA NECRÓPOLIS DE GUADAJIRA (BADAJOZ) Y LA TRANSICIÓN A LA EDAD DEL BRONCE EN LA CUENCA MEDIA DEL GUADIANA
}

\author{
THE GUADAJIRA NECROPOLIS (BADAJOZ) AND THE TRANSITION \\ TO THE BRONZE AGE IN THE MIDDLE GUADIANA BASIN
}

\author{
por \\ VÍCTOR HURTADO PÉREZ* \\ LEONARDO GARCÍA SANJUAN*
}

RESUMEN Se dan a conocer los resultados de la intervención de urgencia realizada en 1990 en la necrópolis de la Edad del Bronce de Guadajira (Badajoz). Una vez analizada la base empírica de esta intervención desde una perspectiva pluridisciplinar (arqueológica, antropológica, arqueometalúrgica y paleobotánica), Guadajira es valorada en el contexto de la transición a la Edad del Bronce en la Cuenca Media del Guadiana y en el suroeste de la Península Ibérica.

ABSTRACT The results of a rescue excavation carried out in 1990 in the Bronze Age necropolis of Guadajira (Badajoz) are presented. Once the empirical basis has been analysed from a pluridisciplinar perspective (archaeological, anthropological, archaeometallurgical and palaeoenvironmental), Guadajira is assessed within the broader context of the transition to the Bronze Age both in the Middle Guadiana Basin and southwestern Iberian Peninsula.

\section{INTRODUCCIÓN}

En 1980 fue excavada junto a la localidad de Guadajira (Badajoz) una estructura funeraria de la Edad del Bronce descubierta de modo fortuito durante el desarrollo de las obras de ensanche de la carretera MadridLisboa que por entonces se realizaban. Este enterramiento (Tumba 1) fue excavado y publicado por uno de los firmantes de este trabajo (Hurtado, 1985), después de que fuera parcialmente alterada por los vecinos de dicha aldea, quienes entregaron los materiales extraídos al Museo Provincial de Badajoz.

* Departamento de Prehistoria y Arqueología (Universidad de Sevilla). 
Diez años más tarde, en 1990, se tuvieron noticias del hallazgo en Guadajira de un enterramiento semejante al registrado en 1980, en circunstancias similares a la anterior (construcción en este caso de la autovía Madrid-Lisboa). La situación de esta segunda tumba (Tumba 2), bien visible junto a la cuneta de la carretera, hizo que fuera rápida y totalmente expoliada, de forma que apenas fue posible documentarla. No obstante, con motivo de la aparición de esta segunda estructura se realizó una prospección superficial intensiva del entorno que permitió hallar una tercera estructura (Tumba 3) en una zona algo más alejada de la carretera. Aunque se encontraba parcialmente alterada, esta estructura conservaba en su situación primaria una buena parte del depósito funerario.

A pesar de una búsqueda minuciosa no se detectaron otros enterramientos en la ladera, aunque no es posible actualmente descartar por completo la existencia de otras estructuras funerarias sin la aplicación de sistemas de rastreo más eficaces. Asimismo, se desconoce la ubicación del asentamiento al que estas construcciones funerarias corresponden, ya que la prospección realizada en sus inmediaciones tampoco facilitó evidencias de la existencia de un hábitat. En la prospección realizada en todo el cerro sólo fueron localizados algunos fragmentos amorfos de cerámica en la ladera occidental que no permiten asegurar si pertenecen al poblado o alguna otra tumba destruida. En el espolón occidental del cerro, idóneo para la situación del poblado, tan sólo existen restos de época romana. También es probable que la construcción en los años 1950 del pueblo de colonización agrícola de Guadajira en la cima amesetada del cerro afectara de forma definitiva al registro arqueológico asociado a este asentamiento prehistórico, de acuerdo a ciertas informaciones orales.

Las estructuras funerarias de Guadajira se encuentran situadas en la ladera sur del cerro que ocupa el actual pueblo de Guadajira, junto al km. 373 de la autovía Madrid-Lisboa (coordenadas 34034768, hoja 776 IGCE $\mathrm{E} / 1: 50.000$ ) y a $30 \mathrm{kms}$. de Badajoz (figs. 1 y 2 ).

Guadajira es una pequeña elevación que se alza unos 30 ms. sobre los llanos de la depresión Augustana, el espolón de una línea de serratas que se levanta paralela al río Guadiana por su margen izquierda. Rodeando el cerro se encuentra el río Guadajira, el cual discurre por el sur y oeste desembocando $2 \mathrm{kms}$. más al norte en el río Guadiana. A pesar su escasa altura, el cerro domina el paisaje aluvial y la penillanura extremeña en la que se encuentra la comarca de Tierra de Barros, una tierra fértil muy apta para el cultivo de cereales, que se extiende monótona por el sur hasta las estribaciones de Sierra Morena (lám. I).

En este trabajo se efectúa una descripción del registro empírico obtenido en la campaña de excavaciones de urgencia realizada durante el verano de 1990 en las estructuras funerarias denominadas Tumba 2 y Tumba 3 de Guadajira, así como una valoración de dicha localización funeraria en el contexto del poblamiento de la primera mitad del II milenio a.n.e. en la Cuenca Media del Guadiana. Así, se procede en primer lugar a realizar una síntesis general de las evidencias actualmente disponibles de cara al estudio de las poblaciones de la Edad del Bronce en este medio geográfico y humano; en segundo lugar se describe el registro realizado en la campaña de excavaciones de 1990, realizándose en tercer y último lugar una reflexión sobre los problemas arqueográficos principales que afectan a la transición a la Edad del Bronce en la Cuenca Media del Guadiana en particular y en el suroeste peninsular por extensión.

\section{EL POBLAMIENTO DE LA EDAD DEL BRONCE EN LA CUENCA MEDIA DEL GUADIANA. EVIDENCIAS EMPÍRICAS}

Cualquier investigación sobre el poblamiento de la Edad del Bronce en la Cuenca Media del Guadiana se enfrenta al obstáculo preliminar de que las evidencias empíricas disponibles en la actualidad no han sido en ningún caso producidas en el marco de Programas de Investigación Sistemáticos que hayan operado en el medio o largo plazo sobre territorios definidos sobre la base de campañas sistematizadas 
de recogida y análisis de datos. Antes al contrario, la información actualmente existente para un estudio de esta naturaleza se ha generado a partir de la acumulación de intervenciones puntuales e inconexas.

El descubrimiento y excavación de la Tumba 1 de Guadajira (Hurtado, 1985) supuso en su momento la primera aproximación al conocimiento de la dinámica cultural de la Edad del Bronce en la Cuenca Media del Guadiana. A excepción de los enterramientos secundarios de Colada de Monte Nuevo de Olivenza (Schubart, 1973) (fig.3, no 23) y algún hallazgo aislado de cistas no se conocían en esta región extremeña necrópolis o poblados que permitieran una valoración sistemática de la ocupación humana del II milenio a.n.e., hasta el extremo de que era generalmente considerado uno de los períodos más oscuros de la prehistoria extremeña (Enríquez-Hurtado, 1986; Gil Mascarell et alii, 1986).

A partir de 1985 se realizan las primeras prospecciones sistemáticas (Rodríguez, 1986; Enríquez, 1989;1990), y se producen nuevas intervenciones puntuales en necrópolis (Gil-Mascarell-Rodríguez, 1986) y asentamientos (Hurtado-Enríquez, 1991), con lo que se comienza a disponer de una base empírica preliminar sobre la que afrontar el análisis del este periodo.

Una importante intervención se verifica en 1987 con la excavación de urgencia realizada en el Castillo de Alange, Badajoz (Calero et alli, 1988; Pavón, 1994) (fig 3, n²5) en donde pudo ser detectada una estratigrafía que abarca todo el II milenio a.n.e. Las primeras excavaciones tuvieron lugar en la solana del cerro y posteriormente se han practicado sondeos en la umbría del mismo (Pavón, 1995a; 1995b) a partir de los cuales de han realizado dataciones absolutas y análisis faunísticos y polínicos. De acuerdo con su excavador, es posible distinguir dos fases en la ocupación de este asentamiento:

- La fase más antigua corresponde a lo que su excavador denomina horizonte epicalcolítico o Solana I y Solana I-II datada entre 1800 y 1.700 a.n.e en la que la cerámica manifiesta un cierto "grado de calcolitización" (Pavón 1994:113) y cuya característica principal la constituye la presencia del grupo de cerámicas de paredes delgadas análogas a las de Guadajira que en los sucesivos estratos muestran una mayor tendencia a la cocción reductora y decoración bruñida. También a esta fase corresponde un enterramiento infantil en covacha hallado en el interior del poblado al que acompañaba como ajuar un cuenco hemiesférico (Pavón, 1995a: 37; 1995b:40).

- La segunda fase, u horizonte de Bronce Pleno se subdivide en Solana IIA en que la cerámica "apunta una fuerte conexión morfológica con el horizonte Atalaia" (Pavón 1995b:824) y IIB separadas por la construcción de una muralla y la aparición de vasos de tipo Santa Vitoria y Odivelas datados por C-14 en 1.570 a.n.e. (Pavón 1995b:829).

El Castillo de Alange, situado en la ladera de un cerro eminentemente estratégico, domina por el norte un vado importante del Guadiana y a su falda sur confluyen tres ríos. La posición del cerro de Alange corresponde a una cadena de sierras que de forma paralela al río Guadiana y en el eje este-oeste se elevan sobre la inmensa planicie que constituye la penillanura extremeña y la misma depresión del río. Es precisamente en esta serie intermitente de elevaciones (en una de las cuales se sitúa el yacimiento de Guadajira), a veces aisladas, donde se localizan hasta ahora las escasas evidencias de asentamientos en altura correspondientes al II milenio a.n.e. Así se conocen restos (escasos) en la Sierra de San Serván, con una cista en las proximidades de Arroyo de San Serván (Enríquez-Jiménez, 1989) y en el Cerro de San Cristóbal en el mismo Badajoz; aquí aparecieron materiales de superficie correspondientes al Calcolítico y Bronce Final entre los que se encuentran "formas relacionables con el Bronce del Suroeste" (Enríquez-Domínguez, 1984:11).

En los alrededores de Alange, donde se ha practicado una de las dos únicas prospecciones sistemáticas de la Cuenca Media del Guadiana (Enríquez, 1990), y próximo al asentamiento del Castillo de Alange, se encuentra el poblado amurallado de La Palacina, "el más importante dentro de la comarca de Mérida durante la 
fase campaniforme" (Enríquez-Jiménez, 1989:85), y que se abandona cuando comienza la ocupación del Castillo de Alange, situado en el paso natural anteriormente mencionado (fig. 3, n⿳⺈ 6).

Más hacia el sur se encuentran los yacimientos de Palacio Quemado, Las Minitas y Los Cortinales, localizados en llano o sobre suaves lomas.

El poblado de Palacio Quemado (fig. 3, no 7) se encuentra a pocos kms. de La Palacina y Castillo de Alange y junto al arroyo Valdemedel que desemboca al pie del Castillo de Alange y en él se han practicado varias campañas de excavación (Hurtado-Enríquez, 1991). Este asentamiento se sitúa en una cota sin defensas naturales que domina el estrecho valle del arroyo pero está rodeado de murallas. Se han identificado dos fases de ocupación (separadas por una destrucción violenta -nivel de incendio), que, de acuerdo con la secuencia estratigráfica y las dos dataciones radiocarbónicas obtenidas, comprenden desde un momento final del III milenio hasta el siglo XVII a.n.e. En las proximidades de este asentamiento se han detectado cistas individuales y dobles sin ajuar funerario.

Recientemente se han realizado intervenciones arqueológicas de urgencia en la necrópolis y asentamiento de un enclave de Edad del Bronce situado en las inmediaciones de Almendralejo y denominado Las Minitas (Pavón, 1995b; Pavón et alii, e.p.) (fig. 3, no 8). En el poblado, que, aunque dominante en el entorno sobre una pequeña loma, se sitúa en cotas muy bajas que carecen de la virtualidad defensiva del Castillo de Alange, se han identificado dos estructuras excavadas de almacenamiento (silos) pero no estructuras de producción o habitación. Los escasos ajuares registrados en los enterramientos (individuales o dobles) han servido a los excavadores para fechar el enclave dentro de la segunda mitad del II milenio a.n.e.

Más al sureste, el poblado de Los Cortinales (Gil Mascarell-Rodríguez, 1985) se sitúa también en llano (fig. $3, \mathrm{n}^{\circ} 11$ ), presentando asimismo estructuras excavadas en el suelo como zanjas y silos, y un repertorio cerámico semejante al de la segunda fase de ocupación de Palacio Quemado. A este poblado parece asociarse la localización funeraria de Las Palomas (Gil-Mascarell et alii, 1986) (fig. 3, no 12) compuesta de enterramientos individuales en cista en la mayoría de los cuales se han identificado recipientes cerámicos que formalmente se asemejan en su totalidad a los tipos que tradicionalmente se han venido adscribiendo al Calcolítico.

Finalmente, el asentamiento de La Pijotilla (fig. $3, \mathrm{n}^{\circ}$ 2), el más cercano a Guadajira, se sitúa en un terreno llano y está delimitado por un recinto defensivo de $1 \mathrm{~km}$ de diámetro que delimita una gran extensión de hábitat de unas 70 has de superficie. Las campañas de excavaciones realizadas en el hábitat y necrópolis de La Pijotilla sugieren que su ocupación se produce durante un periodo básicamente coincidente con el de Palacio Quemado, abarcando el último cuarto del III milenio a.n.e. y el primer cuarto del II milenio a.n.e. En lo que se refiere específicamente al registro de la Edad del Bronce en este asentamiento, la presencia de estructuras funerarias como silos o fosas con enterramientos individuales así como el hallazgo en la zona de hábitat de materiales como un puñal con nervadura central y remache y frecuentes cuencos carenados (Hurtado, 1986; Enríquez-Hurtado, 1986) sugiere la pervivencia de la ocupación de este asentamiento quizás incluso hasta mediados del II milenio a.n.e., aunque por el momento no hay dataciones absolutas que respalden esta suposición.

En la provincia de Badajoz se conocen además otros enterramientos en cista (fig. $3, n^{\circ} 13$ a 22 ) cuya información conjunta fue recopilada por M. Gil-Mascarell y otros (1986) sin que se conozca su relación directa con poblados y cuya distribución parece concentrarse hacia el centro-sur de la provincia, con posible conexión con la aglomeraciones de cistas existentes en la Sierra de Huelva.

Es ésta básicamente la información actualmente disponible para contextualizar el sitio de Guadajira en la dinámica de poblamiento de la Edad del Bronce en la Cuenca Media del Guadiana. Fragmentaria e insuficiente, la base empírica disponible presenta además problemas producidos por posibles sesgos arqueográficos que son discutidos en la ultima sección de este trabajo. 


\section{LOS ENTERRAMIENTOS DE GUADAJIRA. REGISTRO EMPÍRICO}

\section{III.a. La Tumba 1}

En lo que se refiere al sistema de construcción, La Tumba 1 de Guadajira había sido excavada en lo alto de un pequeño montículo rocoso de unos $5 \mathrm{~ms}$ de altura. Ovalada en sección, la forma de la planta era de tendencia circular, de unos $3.5 \mathrm{~ms}$. de diámetro máximo y en el arco mejor conservado se mantenía parte de la pared rocosa hasta unos $0.50 \mathrm{~ms}$. de altura (fig 4). No se advirtieron restos de construccción de la cubierta en el interior, a excepción de algunas piedras situadas alrededor, por lo que de haber existido una falsa cúpula habría sido construida a partir de una determinada altura del zócalo rocoso y desaparecida por efecto de la erosión.

A pesar del saqueo al que fue sometida esta estructura fue posible localizar in situ unos restos óseos muy fragmentarios que sugieren su utilización como enterramiento colectivo. A partir del conjunto de huesos hallados fue posible establecer en un total de cinco o seis el número de individuos enterrados en la Tumba 1.

En lo referente al ajuar funerario, el conjunto de material cerámico procedente de la Tumba $I$ se ha visto incrementado en el transcurso de la campaña de excavaciones de 1990 con la recuperación de material que había sido recogido en 1980 (este material es referido en adelante como Colección Jerez). La gran cantidad de vasos recogidos sugiere que en este mismo lugar debió existir otra u otras tumbas que habrían sido completamente arrasadas por las máquinas durante la construcción de la carretera '. A esta posibilidad apunta el hecho de que en la excavación se apreciaban, efectivamente, agujeros de expoliación, si bien considerando lo reducido de sus tamaños es dudoso que sólo de aquí procedan los 27 vasos completos que figuran entre las piezas extraídas por los dos coleccionistas de Guadajira sobre un total de casi 90 piezas reconstruibles, es decir el $30.6 \%$ del conjunto cerámico. Teniendo en cuenta el número de vasos de posible reconstrucción procedentes exclusivamente de la excavación, se advierte que los vasos completos constituyen el $14.28 \%$ del total localizado in situ. Curiosamente es una proporción similar a la de la Tumba 3 donde los vasos completos constituyen el $17.5 \%$ del repertorio total. Las circunstancias que afectaron a una y otra tumba, efectivamente, no son las mismas, ni tampoco tiene porqué ser similar el número de objetos cerámicos en cada una de ellas, pero extraña la desproporción entre ambas y sobre todo que de las zonas de saqueo no pudo extraerse tanto material, así como que el hallado al pie del montículo no podía proceder de la Tumba 1 pues las máquinas no llegaron a alterar su composición.

El conjunto de vasos rescatado durante la intervención de 1990 no difiere morfométricamente del publicado en 1985. Todos pertenecen a los grupos de vasos pequeños con diámetros que no superan los $12 \mathrm{cms}$. y alturas menores a $7 \mathrm{cms}$. a excepción de un vaso globular que alcanza los $11.5 \mathrm{cms}$ (fig. 5). La diferencia a destacar entre un conjunto y otro es que si en el de 1985 predominaban las paredes delgadas (inferior a 0.5 cms. de grosor), que llegaban a constituir una de las características más sobresalientes, en la Colección Jerez los vasos presentan fundamentalmente paredes medianas.

Morfológicamente las diferencias entre el conjunto de recipientes de 1985 y el actual radican en el predo-

1. Una hipótesis plausible es que existieran otros tipos de enterramiento próximos a la tumba circular, como apuntaba el hallazgo de un vaso esférico en un ángulo formado en la ladera occidental perteneciente quizás a una estructura en fosa (no se conservaban restos de lajas de pizarra) que bien pudiera haber sido de forma rectangular. Lamentablemente fué en la ladera occidental del montículo donde las máquinas excavadoras ocasionaron la mayor destrucción, por lo que de haber existido ahí otros enterramientos desaparecieron por completo. Las noticias obtenidas indican que muchos de los vasos recogidos por los vecinos del pueblo aparecieron en esa zona. 
minio de los cuencos de paredes entrantes del segundo. Mientras que aquí la presencia de este tipo constituye el $40 \%$ del total (fig. 5, $\mathrm{n}^{\circ} 6$ a 8), en los anteriormente publicados, tanto en el conjunto recogido por los coleccionistas como los hallados en la excavación, se reducía a un ejemplar $(0,8 \%)$. A este grupo le sigue el de cuencos carenados de los que se cuentan cinco ejemplares (fig. 5 , no 2 a 4 ) y que constituía el grupo mayoritario y mejor acabado (fina decantación, bruñido y con engobe negro) del conjunto de 1985 . Y por último un vaso esférico o globular (fig. 5, no 1), un vaso hiper-hemiesférico (fig. 5, n⿳o 10), un cuenco hemiesférico (fig. $5, n^{\circ} 5$ ) y otro en casquete esférico (fig $5, n^{\circ} 9$ ), también minoritarios en el estudio anterior.

\section{III.b. La Tumba 2}

La intervención arqueológica de la Tumba 2 fue debida, como se dijo anteriormente, a la casual aparición de su estructura junto a la cuneta de la carretera. El descubrimiento parcial posiblemente fue causado por las remociones de tierras que se realizaron en la construcción de la autovía Madrid-Lisboa y a la erosión producida en la vaguada, de forma que, dada la gran visibilidad que ofrecía al encontrase en un sitio de paso, fue saqueada en su totalidad.

Para la excavación se trazó una línea de $10 \mathrm{mts}$. de longitud en sentido este-oeste que atravesara perpendicularmente la tumba para el estudio en sección de la estructura arquitectónica y el sistema de construcción tumular. A pesar de la fuerte remoción de tierra que se advertía en el interior de la tumba se procedió a la excavación del suelo con objeto de detectar alguna zona que no hubiese sido alterada por los saqueadores. Pero el intento resultó inútil ya que todos los niveles de ocupación originarios habían sido destruidos, llegándose incluso a profundizar en el suelo natural. La única posibilidad que quedaba de rescatar información sobre el contenido funerario se limitaba a cribar toda la tierra existente tanto en el interior como el exterior. Unicamente fueron registrados pequeños fragmentos óseos y dos fragmentos de cerámica (fig. 11, no 1 y 2).

El sistema constructivo de la Tumba 2 resulta diferente al de las tumbas 1 y 3 (fig. 6). La estructura no aprovecha un suelo rocoso sino que se elige uno de los pocos espacios libres de roca, una pequeña vaguada compuesta por un terreno de arcillas rojas muy compactas y una zona de suave pendiente de la ladera para su ubicación. La facilidad de excavar el suelo permitiría que gran parte de la estructura se construyera bajo tierra llegando en la actualidad a conservarse hasta la profundidad de un metro. Sin embargo el levantamiento de la cubierta se realizó mediante la colocación de un grueso muro circular de $0.80 \mathrm{~ms}$. de espesor que, desde el suelo de la tumba y por aproximación de hiladas, componían la falsa bóveda. El muro estaba formado por piedras irregulares bien ensambladas entre sí, con las caras aplanadas vistas hacia el exterior y con reforzamiento de las junturas por medio de tierra y piedras pequeñas que daban a todo el conjunto el aspecto de una cuidada y consistente construcción (lám. II). A pesar de encontrarse en un punto de poca pendiente, su situación en ladera hizo que desapareciera la parte sur, más expuesta a la erosión y donde se situaría el acceso al interior.

La planta circular tiene un diámetro de $2.70 \mathrm{~ms}$. en el eje Este-Oeste y una altura conservada de $1.20 \mathrm{~ms}$. Llama la atención la fuerte inclinación de sus paredes hacia el interior, hasta el punto que llegan a formar un ángulo de 50 grados, que de prolongarse permitiría calcular una altura máxima de $1.60 \mathrm{~ms}$.; ahora bien, si tenemos en cuenta que el sistema de falsa cúpula suele cerrarse mediante la colocación de una losa, sobre todo en las construcciones de bóvedas con piedras irregulares, entonces la altura sería menor, posiblemente 1,30 ms.

Toda la tumba se cubriría con un túmulo. En el sector occidental de la excavación la arcilla roja se encuentra a mayor profundidad, por lo que el muro de la tumba se reforzó aquí desde su misma base mediante el levantamiento de un túmulo de tierra y piedras pequeñas que, hemos de suponer, terminaría por cubrir toda la estructura funeraria. En el sector oriental, sin embargo la misma arcilla roja serviría de sostén por lo que el 
túmulo de cubrición se encontraría a mayor altura y no se ha conservado ningún vestigio. El túmulo abarcaría un diámetro de $8 \mathrm{~ms}$.

Dada la naturaleza del hallazgo, con el saqueo de la tumba y la remoción de los depósitos funerarios, el material osteológico de la Tumba 2 presenta un grado de fragmentación muy alto. De acuerdo con el informe realizado por J.M. Guijo Mauri y J.C. Pecero Espín (1995), la conservación de estos restos osteológicos están en directa relación con la naturaleza reciente del expolio, que ha incidido en un patrón generalizado de roturas recientes que se suman a la detección de otras roturas antiguas, cuya causa y significados son más difíciles de clarificar. Así, se observan:

- Roturas antiguas sobre hueso desprovisto de sustancia orgánica. Tienen líneas de fractura suavizadas y redondeadas y de trayectoria irregular. Se han detectado tanto en fragmentos de cráneo como en huesos largos y podrían estar relacionadas con el ritual, o más probablemente con la naturaleza de los enterramientos colectivos.

- Roturas antiguas sobre hueso desprovisto de sustancia orgánica.

- Roturas recientes. Son las que predominan. Tienen líneas de fractura más regulares, de contornos homogéneos.

- Pigmentación por elementos metálicos. En dos fragmentos de diáfisis de huesos largos del miembro inferior hemos encontrado una coloración verdosa, muy homogénea y con un alto grado de adherencia, propia de una pigmentación ocasionada por contacto prolongado de material metálico (cobre) sobre restos óseos.

- Pigmentación de otros elementos minerales. En relación directa con el ritual se han encontrado probables restos de coloración de ocre sobre restos óseos.

Pese al expolio de la estructura, Guijo y Pecero observan una serie de indicios en la evidencia osteológica que les permiten inferir algunas conclusiones sobre los aspectos rituales:

- Presencia de elementos anatómicos de pequeño tamaño como huesos del tarso y metatarso, carpo y metacarpo, numerosas falanges, restos vertebrales y costales, así como un total de 79 piezas dentales sueltas.

- Existencia de una serie de fracturas presentes en algunos fragmentos de diáfisis, cuya morfología nos habla de roturas antiguas

- Presencia de fracturas antiguas sobre hueso seco.

Esos datos indican la existencia de una serie de alteraciones que afectaron al depósito funerario antiguamente, muy poco tiempo después de las deposiciones de algunos materiales, lo cual podría estar en relación con una reutilización periódica del espacio funerario mientras que los elementos anatómicos presentes parecen sugerir un lugar de inhumación primaria. La Tumba 2 constituiría por tanto una sepultura de inhumación colectiva que podría haber sido reutilizada durante un tiempo imposible de cuantificar. La tinción por óxido de cobre de algunos huesos sugiere la proximidad de un ajuar metálico junto al individuo, mientras que por otra parte se advierten restos de ocre en algunos de los huesos.

En lo que atañe a los aspectos demográficos de la evidencia esquelética, en total se ha identificado un número mínimo de once individuos cuya relación por grupos de edad es la siguiente:

- Infantiles: 1 individuo de edad comprendida entre los 18 meses y los 3 años, 1 individuo de unos 5 años, 1 individuo de unos 7-8 años, 1 individuo de unos 10 años, 1 individuo de 11-12 años, y un último individuo de 13-14 años.

- Adultos: En lo que se refiere a los adultos se ha identificado un número mínimo de 5 individuos, pudiendo ascender hasta un total de siete, por lo que la cifra total de individuos inhumados oscila entre 11 y 13.

En lo referente a la patología y trazas epigenéticas de los restos estomatológicos, la ausencia completa de primeros molares permanentes con semejante grado de desgaste podría estar en relación a una pérdida 
antemortem de los mismos por caries, factor patológico que ha tenido una mayor incidencia histórica en esos dientes. La presencia de cálculo afecta al $12.65 \%$ de las piezas estudiadas, teniendo una localización exclusiva en la región cervical. De acuerdo con Guijo y Pecero, esta afección se puede considerar en términos generales como moderada, sobre todo atendiendo a la comparación de resultados con otras poblaciones calcolíticas, como por ejemplo las estudiadas por E. Chimenos en Cataluña, donde la frecuencia de cálculo sobre 892 piezas dentales procedentes de 5 yacimientos calcolíticos es del 58.07\% (Chimenos, 1990). La caries está presente en un $8.86 \%$ de los dientes estudiados. Si extrapolásemos este porcentaje a la tabla de frecuencias de caries en poblaciones de la prehistoria reciente de Cataluña realizado por Chimenos, se ajustaría a unos patrones intermedios entre poblaciones calcolíticas (5.38\%) y de la edad del bronce (9.24\%) (Chimenos, 1990), coincidiendo también con los porcentajes, que no sobrepasan el 10\% que Brabant ofrece para la edad de los metales en Gran Bretaña (Brabant, 1967:546). No obstante, estas contrastaciones deben tomarse con la reticencia y precaución oportunas que imponen las diferencias geográficas, ambientales y culturales, ante la falta de datos similares para la Cuenca Media del Guadiana. Finalmente, la frecuencia de hipoplasia entre los restos de este enterramiento es de un $11.39 \%$, mientras que, sólo se han podido diagnosticar secundariamente dos casos de periodontitis - cf. discusión pormenorizada en (Guijo-Pecero, 1995).

\section{III.c.- La Tumba 3}

En cuanto a su sistema de construcción, la Tumba 3 es análoga a la Tumba 1 (fig. 7). Se encuentra parcialmente excavada en la roca y su forma es de tendencia circular, con $3 \mathrm{~ms}$. de diámetro en el eje Este-Oeste y una profundidad de $0.50 \mathrm{~ms}$, en el lado norte, el mejor conservado. Presenta una particularidad respecto a las restantes tumbas, una oquedad de forma rectangular excavada en el suelo rocoso junto al lado sur, que mide $0.70 \times 0.60 \times 0.30 \mathrm{~ms}$. (láms. III y IV). La tierra que se encontraba en su interior era de un tono grisáceo, distinto al del suelo de ocupación y sobre ella apareció un vaso (fig. 8, no 4) y un fragmento de una pieza de cobre (fig. $13, n^{\circ} 5$ ) que acreditarían el sellamiento de esta estructura antes de la deposición del ajuar. Dentro no apareció más que un fragmento de cerámica (fig. 11, $\mathrm{n}^{\mathrm{O}} 24$ ), un cuenco de factura tosca, con mucho desgrasante medio y sin tratamiento superficial y piedras pequeñas; no había ninguna evidencia que indicara su funcionalidad en el interior de la sepultura.

En cuanto al ajuar funerario, en total se recogieron 40 recipientes cerámicos contabilizando los fragmentos de bordes de posible reconstrucción: 7 completos, 7 semicompletos y 26 fragmentos de bordes. El mayor porcentaje corresponde a recipientes de pequeño tamaño, cuyo diámetro de boca no supera los $10 \mathrm{cms}$. y con alturas medias de $5 \mathrm{cms}$.; tan sólo dos cuencos de borde entrante y uno hemiesférico alcanzan diámetros de 18 cms. (fig. 10, n⿳o 15 y 16), si exceptuamos un fragmento de plato (fig. 11, $\mathbf{n}^{\mathrm{o}} 25$ ), cuyas dimensiones podrían llegar a los $30 \mathrm{cms}$.

Desde un punto de vista morfométrico - cf. discusión más adelante - el mayor grupo de artefactos cerámicos (57.5\%) corresponde a aquellos en que el diámetro máximo se encuentra situado en el galbo y con el borde inclinado hacia el interior presentando la pared una inflexión o quiebro más o menos acusada que no llega a suponer carena. En conjunto forman un amplio grupo de los denominados cuencos de borde entrante, que podemos subdividir entre aquellos que tiene el diámetro máximo en el tercio superior (12.5\%), de tendencia hemiesférica y borde indicado al interior (fig. 9, o 7 a 9), los cuencos con diámetro máximo a media altura (40\%), unos con suave carena y perfil bitroncocónico (fig. 8, $\mathrm{n}^{\circ} 4$ a 6), otros de perfil elipsoide, los característicos cuencos de borde entrante (fig. $9, \mathrm{n}^{\mathrm{o}} 10$ y 12 ;fig. $10, \mathrm{n}^{\mathrm{o}}$ 16) y aquellos con diámetro máximo en el tercio inferior (5\%) y perfil troncocónico (fig. $10, \mathrm{n}^{\circ} 13$ y 14) de paredes medianas y factura tosca.

A este grupo le sigue el de cuencos hemiesféricos que suponen el $22.5 \%$ (fig. 10, $\mathrm{n}^{\mathrm{o}} 15$; fig. $11, \mathrm{n}^{\mathrm{o}}$ 17,18,21 
a 23), y ya en menor proporción el de cuencos carenados de pared vertical, con el $7.5 \%$ (fig. 8, no 2 y 3), tres en forma de casquete esférico el $7.5 \%$ (fig. $11, \mathrm{n}^{\circ} 20,24$ y 25 ) y un vaso esferoide con borde indicado (fig. $8, \mathrm{n}^{\mathrm{o}} 1$ ).

Sin embargo, atendiendo al estado de conservación de las piezas halladas en el nivel base, todos los recipientes que se encontraron completos pertenecen al grupo de los cuencos bitroncocónicos y troncocónicos, con los diámetros máximos a media o baja altura (fig. $8, \mathrm{n}^{\circ} 4$ y 6 ; fig. $10, \mathrm{n}^{\mathrm{o}} 13$ y 14). Solamente fueron siete (el $17.5 \%$ del total) los recipientes que se encontraban completos en el momento del hallazgo; los de mayor tamaño y paredes gruesas se conservaban en mejores condiciones, los más pequeños y de paredes delgadas o estrechas aparecieron fragmentados, a excepción del cuenco $\mathrm{n}^{\mathrm{o}} 12$ que se encontró intacto y en posición invertida.

En la Tumba 3 predomina la cerámica de cocción reducida, aunque en la mayoría de los casos la pasta presenta irregularidades de cocción ofreciendo en la superficie poca homogeneidad en cuanto a coloración. También predominan las arcillas bien decantadas, con desgrasante fino en los vasos pequeños y un acabado pulido de las superficies. En el tratamiento superficial destaca, además, el bruñido que se aprecia en algunos recipientes, pero especialmente se advierte una pigmentación de color negro que una vez analizada (XRF) ha resultado pertenecer a restos de manganeso con el cual se cubriría la totalidad de las superficies dando a estas un aspecto negro y brillante.

En la Colección García Méndez, también de Guadajira y procedentes de esta tumba se encuentra la mitad superior de un vaso campaniforme completamente decorado a base de bandas horizontales paralelas en las que alternan dos motivos incisos de líneas quebradas formando triángulos continuos y pequeñas incisiones verticales. El vaso es de cocción reducida interior y oxidante exterior, desgrasante medio y presenta en la superficie una coloración rojiza algo bruñida y restos de incrustración de pasta blanca (fig. 12). También se encuentra en esta misma colección un pequeño fragmento amorfo de cerámica campaniforme decorado con motivos incisos de tres líneas anchas en zig-zag enmarcadas por otras líneas más finas, rectas y paralelas dispuestas en horizontal (fig. 11, n⿳⺈ 26). La cocción es reducida, con desgrasante fino, de color marrón rojizo exterior y grisáceo en el interior y acabado alisado.

En el interior de la tumba se encontraba, como ya ha sido mencionado, una punta de flecha de cobre completa, el pedúnculo de otra y un fragmento de una pieza que posiblemente corresponda al extremo del enmangue de un puñal de lengüeta (fig. $13, \mathrm{n}^{\circ} 6$ ).

El Sr. Garcia Méndez de Guadajira afirmó haber localizado junto a los fragmentos campaniformes y dos vasos (fig. 8 , $n^{\circ} 6$; fig. $11 n^{\circ} 17$ y 26 y fig. 12) otras cuatro puntas de flecha (fig. 13 , $n^{\circ} 1$ a 4 ) que por las referencias dadas todas procederían del sector nororiental de la tumba, muy próximo al conjunto de vasos hallado en la excavación. También confirmó que la mitad occidental de la tumba se hallaba removida por los saqueadores y que era probable que el resto del vaso campaniforme hubiera sido extraído anteriormente. La fractura del fragmento es efectivamente antigua y posiblemente el vaso se encontraba separado por lo que al localizar la pieza el expoliador debió creer que se trataba de un vaso completo y desistió en la búsqueda. La punta de flecha completa y el fragmento de puñal han sido analizados en el Departamento de Física Atómica y Nuclear de la Universidad de Sevilla, obteniéndose la siguiente composición:

\begin{tabular}{lrr}
\hline & PUNTA & PUÑAL \\
\hline CU & $93,38 \%$ & $91,46 \%$ \\
AS & $3,34 \%$ & $4,45 \%$ \\
SN & $0,35 \%$ & $0,38 \%$ \\
FE & $0,64 \%$ & $0,62 \%$ \\
BA & $3,29 \%$ & $3,09 \%$ \\
\hline
\end{tabular}


Los resultados revelan una alta proporción de arsénico y la similitud en la caracterización y porcentaje de los componentes de ambas piezas de forma que podrían proceder de un mismo conjunto minero-metalúrgico.

Las puntas de flecha corresponden al tipo denominado Palmela, con pedúnculos cortos y refuerzo central, presentando una sección amesetada con apuntamiento hacia los bordes y pedúnculos de sección cuadangular y estrechamiento hacia el extremo basal.

El fragmento $n^{\circ} 6$ podría, como se ha mencionado anteriormente, corresponder al extremo de un puñal de lengüeta tipo campaniforme, aunque el enmangue resulta bastante corto. Presenta una sección aplanada, de tendencia rectangular y mismo grosor en todos los puntos. El extremo inferior comienza a ensancharse y a partir de aquí posiblemente se situaría la hoja del puñal, fracturada de antiguo y de la que no se ha encontrado ningún resto en el interior de la tumba.

En cuanto a las evidencias osteológicas, en la Tumba 3 se identifican un total de 2 individuos en base a la existencia de 7 fragmentos craneales, tres de los cuales probablemente correspondiente al frontal o parte anterior del parietal y otro de ellos al occipital (Guijo-Pecero, 1995). Entre tales fragmentos pueden identificarse por el grosor de la tabla craneal y las dimensiones generales de las porciones conservadas un individuo infantil de menos de 10 años. Un fragmento de parietal puede atribuirse a un individuo adulto por el grosor de la tabla.

Entre los restos procedentes de este enterramiento ha sido posible identificar parcialmente algunos indicios correlacionables con el ámbito ritual, tales como:

- Pigmentación verdosa que afecta a la mitad interna de un fragmento de frontal, en relación a un contacto continuado con elementos metálicos de cobre. La coloración descrita se prolonga por la cara endocraneal, lo cual resulta indicativo de un hecho antiguo que se relaciona cronológicamente con el momento de deposición, o bien con un factor de remoción postdeposicional. En el primer caso se produciría la inhumación del cráneo fragmentariamente. En el segundo, factores rituales o alteraciones postdeposicionales que desconocemos producirían la rotura del cráneo.

- Pigmentación de ocre en una vértebra sacra infantil, sobre la cara posterior.

- Rotura antigua con morfología dentada en fragmento de diáfisis de hueso largo que podría corresponder a una fractura antigua sobre hueso fresco, aunque el fragmento conservado es demasiado insignificante como para poder sacar consecuencias a nivel ritual.

Por otra parte, sobre una muestra de tierra extraída de un vaso de la Tumba 3 se ha realizado un análisis de los restos polínicos en orden a investigar la posible presencia de deposiciones vegetales o florales como parte del ritual funerario - cf. estudios semejantes sobre muestras tomadas del sedimento de relleno de vasos cerámicos depositados en enterramientos de la Edad del Bronce en otros contextos (Varela Gomes, 1994; Tipping, 1994).

El resultado de los análisis polínicos (Martín Consuegra, 1995) indica un predominio de especies herbáceas mayoritariamente antrópicas (85.75\%) sobre las especies arbóreas (14.25\%) (fig. 14). Los datos apuntan a que los sedimentos proceden de un contexto fuertemente antropizado. La aparición de Asphodelus, aunque en bajas proporciones, señala incendios, posiblemente realizados para deforestar la zona. La presencia de Quercus y Olea indica cierta influencia de bosque mediterráneo, mientras que Fraxinus, Salix y Cyperaceae sugieren la cercanía de un curso de agua. Es de destacar el nivel elevado de Paronychia, taxón que crece en zonas ruderales y terrenos pedregosos, presentando un crecimiento en manchas. Esto hace pensar que al estar el enterramiento en una zona de roca excavada, la planta podría haber proliferado entre huecos del roquedo.

También se han encontrado niveles muy altos de esporas del hongo Chaetomium, especie celulolítica, destructora de paja, lana, algodón, lino e incluso otros productos vegetales y animales. Las condiciones físico- 
químicas existentes en el interior de la vasija, junto con su contenido (si lo hubiera), favorecerían la proliferación de este tipo de hongo.

La comparación con el análisis efectuado sobre muestras de adobe de una cabaña de La Pijotilla (aunque de escasa variabilidad en los resultados de este yacimiento) manifiesta un predominio absoluto de las asteráceas (59\% del total). Aunque el predominio es normal en yacimientos de esta época aquí solo puede explicarse desde el punto de vista edáfico y gracias a una fuerte antropización de los sedimentos. Las especies arbustivas y herbáceas apenas están representadas y este extremo podría explicarse por un intenso pastoreo en la zona que habría provocado un paisaje adehesado, similar al que se encuentra en muchos lugares actuales de Extremadura y especialmente de la provincia de Cáceres. Pero también existe una importante presencia de cereales (no bien documentados en el análisis polínico, en el que sólo aparecen crucíferas), como el trigo, cebada y leguminosas como el de habas (Vicia Faba minor). Entre los taxones arbóreos de La Pijotilla domina el Quercus de tipo perenne (encina), con un $74 \%$ relativo y un $27 \%$ respecto a la totalidad. También aparecen taxones de oleáceas en proporciones tan bajas como en Guadajira.

En general, el ambiente vegetal que sugieren los datos polínicos de Guadajira implica una climatología seca coherente con las condiciones más secas que el Periodo Subboreal (c. 2500-700 a.n.e. aprox.) impone respecto del precedente Periodo Atlántico (c. 5500-2500 a.n.e. aprox.). Desde el punto de vista económico, el alto porcentaje de Quercus en el entorno de La Pijotilla sugiere la importante extensión del encinar, lo cual remite a la valoración realizada por A.C. Stevenson y D. Moore (1988) de las columnas polínicas de la Laguna de las Madres y de El Acebrón (El Rocío, Huelva), en la dirección de enfatizar la importancia económica del aprovechamiento forestal y ganadero de los espacios adehesados, esenciales en la producción subsistencial de numerosas comarcas del suroeste peninsular hasta bien entrado el presente siglo (por ejemplo en el caso de la Sierra de Huelva), ya durante las edades del Cobre y del Bronce. También en el caso del asentamiento de la Edad del Bronce de El Trastejón (Zufre, Huelva) la especie arbórea dominante es la encina con un $12 \%$ del total de especies vegetales y un 53.7\% del total de especies arbóreas - cf. una discusión más detallada de estos datos en (Hurtado-García Sanjuán, 1994; Hurtado et alii, 1994).

\section{VALORACIÓN DE LA NECRÓPOLIS DE GUADAJIRA EN EL CONTEXTO DE TRANSICIÓN A LA EDAD DEL BRONCE EN LA CUENCA MEDIA DEL GUADIANA}

\section{IV.a. Registro funerario}

Entre c. 1800 y 1600 a.n.e. se produce en la Cuenca Media del Guadiana una fuerte implantación de la inhumación en contenedores funerarios individuales y un retroceso proporcional de las inhumaciones en contenedores funerarios colectivos. El proceso de extensión en este momento de los enterramientos individuales es común a todo el suroeste de la Península Ibérica y constituye en realidad uno de los demarcadores arqueográficos más inmediatos del tránsito entre la Edad del Cobre y la Edad del Bronce. Los enterramientos colectivos no desaparecen, pero pasan a constituir una minoría frente a la extensión de los enterramientos individuales. Quizás el ejemplo más representativo se observe en la reutilización en esta etapa del tholos de Colada de Monte Nuevo (Schubart, 1973) Dos tipos de contenedores funerarios definen el patrón de enterramiento en esta etapa: enterramientos individuales en fosa, silo o covacha, que siguen siendo relativamente abundantes en zonas como el bajo valle del Guadalquivir, y enterramientos individuales en cista.

A escala regional, la lectura arqueográfica de la transición entre ambos momentos funerarios (predominio 
del enterramiento en cámara colectiva vs. predominio del enterramiento en cámara individual) es por el momento complicada por la ausencia de un número suficiente de referencias cronológicas absolutas. En general, algunas necrópolis de características híbridas pueden ser interpretadas como representativas del proceso de transición hacia la individualización del espacio funerario. Tal es el caso de pequeños sepulcros colectivos como El Tejar (Belén-Amo, 1985), o los tres enterramientos de la propia Guadajira. Estos enterramientos contenían un número reducido de individuos ( 2 a 5 ) y sus materiales presentan más semejanzas formales con los procedentes de los enterramientos individuales en cista que con los de los enterramientos colectivos. Semejante es èl caso también de Los Algarbes (Posac, 1975) donde, además de que los materiales hallados en los sepulcros presentan analogías formales con los de los enterramientos individuales más que con los de los enterramientos colectivos, uno de los sepulcros era individual.

En el caso particular de la Cuenca Media del Guadiana, para comprender el proceso de cambio que se produce en los sistemas de enterramiento entre $c .1800$ y 1600 a.n.e. y en el que se inscribe la necrópolis de Guadajira, resulta fundamental atender a las evidencias que aporta el yacimiento de la Pijotilla, en el que se encuentra una interesante diversidad de construcciones sepulcrales. Por el momento se conocen dos tholo $i$ (tumbas 1 y 3 ) con enterramientos colectivos que contienen más de un centenar de inhumaciones (la tumba 3 alcanza los 300 individuos), una sepultura circular (tumba 2) también colectiva y con ajuar campaniforme, varios enterramientos individuales en silos y una fosa en cuyo interior aparecieron dos cráneos.

Mientras que los tholoi de La Pijotilla corresponden a las fases anteriores al campaniforme, en la tumba 2 circular aparece material campaniforme, como vasos de tipo marítimo y cuencos con ónfalo. El repertorio de formas cerámicas se caracteriza especialmente por el pequeño tamaño de los recipientes, algunos de paredes delgadas, pero entre ellos no figuran los cuencos carenados ni de borde entrante. De forma intrusiva y en el perímetro de esta tumba se abrió una fosa en forma ochavada conteniendo dos cráneos (masculino y femenino) y un pequeño cuenco de factura tosca y mal conservado. Se conocen formas similares en Valencina de la Concepción (Sevilla), cuyo mejor exponente sería el denominado tholos del Cerro de la Cabeza (FernándezRuiz, 1978), el tholos de La Zarcita en Huelva con puntas Palmela entre su ajuar (Cerdán-Leisner-Leisner, 1952). Tumbas circulares u ovales con ajuar campaniforme y enterramiento colectivo tienen su mejor caracterización en diversos puntos del oeste y norte de la Península Ibérica (Barandiarán, 1978).

Sin embargo, la naturaleza constructiva de las estructuras funerarias de Guadajira difieren considerablemente en cuanto a su construcción del enterramiento circular de La Pijotilla. En La Pijotilla el sistema consiste en delimitar la estructura mediante lajas de pizarra hincadas verticalmente en una pequeña fosa y con una (supuesta) recubrición tumular de tierra. Las diferencias también se advierten en el lugar de ubicación puesto que las tumbas de Guadajira se construyen en la misma ladera de un cerro (tumbas 2 y 3 ) o en lo alto de un pequeño montículo (Tumba 1), mientras que en La Pijotilla es en llano. Ambos enterramientos se asemejan en el ritual colectivo, en la tendencia al empleo de vasos pequeños y en la incorporación de elementos campaniformes, aunque difieren las formas cerámicas, el porcentaje de algunas de ellas y el estilo de la decoración campaniforme (marítimo en Pijotilla, inciso en la tumba 3 de Guadajira); por otra parte en Guadajira desaparecen todos los artefactos de carácter ideotécnico.

Los artefactos cerámicos depositados como ofrenda funeraria en los enterramientos de Guadajira presentan unas características morfométricas bastante homogéneas. Si en general los artefactos cerámicos procedentes de contextos funerarios de la Edad del Bronce en el suroeste de la Península Ibérica son de pequeñas dimensiones, en el caso de los vasos cerámicos de Guadajira esta tendencia se agudiza bastante. Las medidas de tendencia central y dispersión de las variables altura máxima y diámetro máximo de los 56 recipientes cerámicos completos procedentes de los enterramientos de Guadajira, muestra que el vaso-tipo utilizado con fines votivos apenas tiene $5 \mathrm{cms}$ de altura por $9.5 \mathrm{cms}$ de diámetro máximo (fig. 15).

En las tablas de frecuencias y en los histogramas ajustados (figs. 16,17,18) se aprecia el predominio de 
los intervalos comprendidos entre 4 y $8 \mathrm{cms}$. Los valores medios de estas mismas variables en muestras de vasos procedentes de contextos funerarios de la Sierra de Huelva y de un grupo de otras localizaciones del suroeste son algo mayores (fig. 15). Por contra, si se comparan los coeficientes de variabilidad para ambas variables en las tres muestras se observa que en Guadajira, es decir a escala semimicro, los valores son relativamente bajos 2 (tendencia a la estandarización en la producción ${ }^{3}$ ), mientras que en sucesivas escalas macro (comarca de la Sierra de Huelva y cuadrante suroccidental de la Península Ibérica) el coeficiente de variabilidad aumenta bastante, disminuyendo correspondientemente la tendencia a la estandarización morfométrica.

La variación en cuanto a la forma de los recipientes no es muy amplia, sentido en el que la cerámica funeraria de Guadajira en particular y el suroeste en general es diferente de la argárica ${ }^{4}$. Las formas compuestas en los ajuares de Guadajira son muy poco diversificadas, y no existen recipientes de gran tamaño ni con suspensiones como los depositados en enterramientos de otras comarcas del suroeste.

Sobre la base de los 56 recipientes intactos registrados en los enterramientos de Guadajira se ha realizado un ensayo de clasificación morfométrica 5 . Para describir la forma de los recipientes cerámicos se ha utilizado mediciones de la altura máxima (i.e. distancia borde-fondo) y de sucesivos diámetros tomados a un intervalo fijo de aquella (es decir, se ha medido la altura máxima y, una vez divida ésta en cinco partes, se han registrado los valores de los diámetros superior, medio e inferior. Una quinta variable tenida en cuenta ha sido la distancia carena-borde. De esta manera se obtiene una síntesis numérica bastante precisa de, por una parte, el tamaño general del recipiente y por otra de su forma.

En el análisis de componentes principales, bastante representativo ya que los dos primeros componentes resumen el $73.16 \%$ de la variación total, se produce un agrupamiento significativo (fig. 19) en el que el primer componente cuenta para el tamaño general del recipiente (a la derecha los de mayor tamaños, a la izquierda los mas pequeños) y el segundo componente para la presencia/ausencia de carena y ubicación de la misma en el perfil del vaso. En la parte positiva del segundo eje se define una gran agrupación que reune las formas compuestas de la muestra (es decir, los vasos carenados); en el Grupo Ia los vasos tienen la carena en el tercio inferior y son muy exvasados (diámetro máximo en la boca), mientras que en el Grupo Ib aparecen vasos cuya carena está en el tercio medio y cuyo borde es entrante, por lo cual el diámetro máximo está en el tercio medio (precisamente en la carena). En la parte positiva del primer componente aparecen cinco vasos (Grupo II) que se caracterizan por ser los de mayor tamaño de toda la muestra (el valor medio de la variable altura es en este grupo casi el doble de la media general de la muestra) y por presentar el diámetro máximo en el tercio medio o inferior. En la parte central del diagrama se define un tercer grupo (Grupo III) que representa la morfometría más habitual entre los vasos votivos de Guadajira (tanto así que los valores medios de las variables altura máxima y diámetro máximo son una réplica casi exacta de los valores que tienen para la muestra en conjunto), es decir, pequeños cuencos exvasados o de borde ligeramente entrante (diámetro máximo en la boca o en el tercio superior). Finalmente, en la parte negativa del segundo componente aparece un último grupo morfométrico (Grupo IV) que incluye vasos de muy poca altura y gran diámetro máximo $(12.1 \mathrm{~cm}$ de media) situado en la boca, es decir, son cuencos casi sin fondo pero (relativamente) muy abiertos.

2. Comparando los coeficientes de variabilidad de ambas variables para los vasos de las tumbas 3 y 1 tomados separadamente (i.e. escala micro) se observan valores aún más bajos.

3. Discusión a este respecto en (Estévez-Lull, 1984).

4. En el caso de los recipientes cerámicos funerarios del II milenio a.n.e. en el sureste peninsular ya existen excelentes clasificaciones estadísticas- cf. por ejemplo (Lull, 1983; Contreras et alii, 1988).

5. Se trata de un ensayo de la clasificación estadística que desde el Proyecto Sierra de Huelva (Hurtado, 1994) se está realizando del material cerámico procedente de los enterramientos de la Edad del Bronce del suroeste peninsular. 
En síntesis, la clasificación estadística de los recipientes cerámicos de las tumbas de Guadajira resultaría así:

- Grupo I:

Formas compuestas (vasos carenados) de dimensiones típicas.

- Subgrupo Ia : carena baja (tercio inferior) y diámetro máximo en la boca.

- Subgrupo Ib : carena media (tercio medio) y diámetro máximo en la carena.

- Grupo II:

Formas simples (ollas): diámetro máximo en el tercio medio o inferior y dimensiones por encima de la media.

- Grupo III:

Formas simples (cuencos): diámetro máximo en la boca o en el tercio superior y dimensiones prototípicas.

- GrupoIV:

Formas simples (cuencos): diámetro máximo en la boca y dimensiones por debajo de la media (especialmente la altura).

Esta agrupación de los recipientes cerámicos hallados en los enterramientos de Guadajira se contrasta favorablemente por el resultado de un análisis de conglomerados realizado mediante la técnica del vecino más próximo sobre una matriz de similaridad calculada a partir del coeficiente de distancia euclidiana (fig. 20) y puede ser por tanto considerada operativa, si bien será más significativa una vez se integre en una clasificación más amplia que incluya items de otras necrópolis de la Edad del Bronce del suroeste.

Finalmente, en lo que se refiere a los aspectos tecnológicos del utillaje cerámico, en la actualidad se está desarrollando un amplio trabajo de muestreo y análisis de cerámicas prehistóricas del suroeste español por parte de tres departamentos de la Universidad de Sevilla (Prehistoria y Arqueología, Física Atómica y Nuclear y Cristalografía, Mineralogía y Química Agrícola) que integra y engloba a Guadajira y otros asentamientos y necrópolis de la Edad del Bronce. No estando los resultados de estos trabajos todavía disponibles, los valores concernientes a Guadajira de los parámetros referidos de forma tradicional dentro de este apartado (fig. 21) no sugieren la existencia de una variabilidad muy amplia dentro de un mismo enterramiento o de los enterramientos entre sí. La arcilla utilizada en la elaboración de los recipientes es bastante fina tanto en el caso de la Tumba 3 como de la Tumba 1, mientras que ambos casos predominan los tonos superficiales oscuros, producto de una cocción reductora. La única diferencia aparente en la manufactura de los recipientes cerámicos es la mayoritaria presencia de un engobe de color negro (manganeso) en los vasos de la Tumba 3 que está completamente ausente en los vasos de la Tumba 1 .

Los items metálicos de Guadajira se limitan a las puntas Palmela y el posible fragmento de puñal procedentes de la Tumba 3, aunque, como ya se indicó los restos de oxidación de cobre adheridos a huesos de la Tumba 2 indicarían la existencia de objetos metálicos entre su ajuar. Las puntas de tipo Palmela han venido siendo tradicionalmente asociadas al denominado horizonte Campaniforme junto con los puñales de lengüeta. Sin embargo, recientes investigaciones sugieren que en realidad, este tipo de items aparecen tanto en contextos precampaniformes como postcampaniformes.

Las puntas de flecha de Guadajira corresponden morfológicamente al tipo tradicional de Palmela, de las cuales existen escasos ejemplares en la Cuenca Media del Guadiana, unos en contexto funerario como en la segunda ocupación del tholos de Colada de Monte Nuevo, junto a un repertorio de formas cerámicas similar a las de Guadajira (Schubart, 1973), otros asociado a cerámica campaniforme en el dolmen de Lácara de Mérida (Delibes, 1977:108) y otros en superficie de poblados como Alangón (Enríquez, 1990:fig. 37,1) o La Pijotilla.

En La Pijotilla (Hurtado, 1984) se encuentra el mayor número de piezas metálicas de toda la región, 
aunque la mayoría procede de hallazgos superficiales. Cabe señalar que de los 50 artefactos metálicos localizados hasta ahora 15 son artefactos de posible naturaleza sociotécnica ${ }^{6}$, como puñales (7), puntas tipo Pastora (2), puntas Palmela (4), puntas de refuerzo (2), mientras que los 35 restantes constituyen artefactos tecnómicos (medios de producción) tales como hoces (9), escoplos (6), sierras (3), cuchillos (3), punzones (2), objetos de adorno (5), hachas (1), anzuelos (1) y otros varios de tipología imprecisa.

Por otra parte el análisis de composición elemental de dos piezas de Guadajira muestra un alto porcentaje de arsénico, llegando a alcanzar en un caso el $4.45 \%$. La aparición de arsénico es común también en mayor o menor proporción entre los componentes de los artefactos metálicos de La Pijotilla ${ }^{7}$ siendo frecuente la cifra entre $2.50 \%$ y $3.50 \%$ de As y alcanzando en ocasiones la de $4.10 \%$ en piezas como un puñal con nervio central y remache, considerado de tipología avanzada; en general una cantidad de arsénico incluso más elevada que la existente en artefactos metálicos de cronología del Bronce, como el puñal y alabarda de Setefilla con 3.70\% (Aubet-Serna, 1981; Aubet et alii, 1983), aunque también existe algún ejemplo excepcional de proporción superior en el caso de un puñal datado en el horizonte Ferradeira según sus autores con un contenido de 6.70\% de As (Rivero-Vázquez, 1988:216). Todos los objetos metálicos datados en la Edad del Bronce procedentes del Castillo de Alange han proporcionado arsénico en proporciones que oscilan entre $0.56 \%$ y $3.08 \%$, similar a la que presenta el conjunto de piezas de la necrópolis de cistas de Las Minitas, entre las que se encuentra una con aleación de estaño en cantidades de $1.47 \%$.

El resultado de los análisis arqueometalúrgicos preliminares de Guadajira plantea el problema de si los cobres arsenicales son producto de una aleación intencionada (en la que se implicita una evolución, un desarrollo tecnológico previo a la aparición del bronce), si son consecuencia puramente de una aleación fortuita, o si por el contrario son consecuencia de una selección intencionada de minerales polimetálicos de cobre y arsénico. La mayor parte de las investigaciones arqueometalúrgicas realizadas sobre cobres arsenicales, tanto en la Península Ibérica (Delibes et alii, 1989; Rovira-Montero, 1994; Montero, 1992a;1992b) como en otras experiencias europeas (Budd, 1992), sugieren la no intencionalidad de las aleaciones Cu-As mientras "los porcentajes de arsénico no respondan a criterios funcionales o tecnológicos, o que obedezcan a un modelo de comportamiento coherente y no azaroso, y mientras los minerales disponibles en un entorno cercano no justifiquen con su composición polimetálica los niveles de arsénico de los productos acabados" (RoviraMontero, 1994:166). A este respecto y a pesar de que no ha concluido la investigación, conviene señalar que los escasos minerales con malaquita hallados en La Pijotilla contienen efectivamente arsénico, aunque con una proporción inferior al 1\%, pero no existen en un radio de aproximadamente $100 \mathrm{kms}$. lugares de mineralización de cobre que permitan conocer con más exactitud la procedencia de los minerales (muy escasos) y artefactos metálicos de Guadajira y La Pijotilla.

En definitiva el carácter tecnológico de las puntas Palmela de Guadajira no indica que se trate de piezas evolucionadas, aunque se podría avanzar la concordancia que en ambos aspectos (morfológico y tecnológico) presentan con las halladas en La Pijotilla, haciéndose necesaria una investigación arqueometalúrgica en el territorio extremeño y por extensión en todo el suroeste.

\section{IV.b.- Registro habitacional}

En lo que se refiere a los asentamientos, ya ha quedado de manifiesto la escasez de evidencias actualmente disponibles para realizar inferencias sobre la evolución de los patrones de asentamiento del II milenio a.n.e.

6. Las puntas de flecha pueden relacionarse igualmente con la caza y no necesariamente con la guerra.

7. Los objetos metálicos de la Pijotilla están siendo estudiados en la actualidad mediante diversas técnicas por M. Hunt. 
en la Cuenca Media del Guadiana. Este problema debe ser observado desde una perspectiva más amplia, ya que parece en realidad constituir un problema arqueográfico generalizado en todo el cuadrante suroccidental de la Península Ibérica.

En conjunto, si se consideran los datos procedentes de todas las cartas arqueológicas publicadas de comarcas del suroeste peninsular (Amores, 1982; Ruiz Delgado, 1985; Rodríguez Díaz, 1986;Oria et alii, 1990; Fernández Caro, 1992; Calado, 1993) ${ }^{8}$, se observa una tendencia a la disminución en el número total de localizaciones con respecto a la etapa precedente así como con respecto a las etapas posteriores (fig. 22). Este hecho puede ser en principio interpretado de dos formas:

A. Por una parte, no se debe descartar totalmente que responda a causas estrictamente arqueográficas y no históricas, es decir, no se puede descartar la posibilidad de que la disminución del número de asentamientos observados fechables entre $c .1700$ y 1100 a.n.e. se deba a cualquiera de estas dos razones:

- A una errónea ubicación temporal de determinados artefactos-guía que suelen servir para insertar en el tiempo aquellos yacimientos conocidos únicamente a través de prospecciones y de cuya cronología no se tienen referencias absolutas. Si los artefactos (generalmente formas cerámicas) que sirven para identificar localizaciones del periodo $c$. 2500-1700 a.n.e. se prolongan hacia el siguiente periodo $c$. 1700-1100 a.n.e., entonces quizás la disminución del número de asentamientos es sólo aparente y no histórica, en cuyo caso tan solo la paulatina acumulación de dataciones absolutas permitirá clarificar el verdadero ámbito del poblamiento de esta etapa respecto a la anterior.

- A que exista un fuerte continuismo entre los asentamientos de c. 1700-1100 a.n.e. y los de c. 1100750 a.n.e., de forma que, superficialmente, son sólo evidentes los vestigios materiales correspondientes a la segunda de estas etapas; de hecho, tres de los cuatro asentamientos de $c .1700-1100$ a.n.e. hasta ahora excavados en el suroeste, El Trastejón, Castillo de Alange y Setefilla, muestran una sustancial continuidad de poblamiento entre ambas etapas.

B. Por otra parte, si se acepta la premisa de que la lectura arqueográfica que sobre bases tradicionales se ha realizado para datar asentamientos en las varias cartas arqueológicas disponibles para el conjunto del suroeste peninsular es correcta, entonces podría inferirse que dentro de este periodo se produce una contracción demográfica y una disminución de la densidad del poblamiento humano y/o una nuclearización de ese poblamiento en un menor número de centros que sean sin embargo mayores y estén más densamente poblados.

La explicación a la disminución del número de localizaciones observadas dentro de esta etapa puede estar en la acción conjunta de varias de las variables mencionadas. La expansión del poblamiento humano a partir de c. 2500 a.n.e. se hace muy visible arqueológicamente en la Cuenca Media del Guadiana porque implica una fuerte cantidad de asentamientos ex-novo en espacios anteriormente deshabitados; quizás el patrón de poblamiento dentro de la siguiente etapa se contrae, concentrándose en un menor número de núcleos, al tiempo que se da una continuidad dentro de la subsiguiente etapa $c$. 1100-750 a.n.e. que impide observar directamente las evidencias de ocupación precedentes.

Sin embargo, la evidencia de que, tomadas separadamente, todas las Cartas Arqueológicas anteriormente citadas describen un descenso en el número de asentamientos clasificados dentro de la Edad del Bronce respecto de los adscritos a la Edad del Cobre, sugiere que una de las cuestiones de mayor importancia que

8. Desafortunadamente, el magnífico inventario de yacimientos arqueológicos de varios de los concelhos que integran el Algarve portugués (Marques, 1992) no delimita la cronología de las localizaciones lo sufiente como para que la información pueda ser integrada en la discusión de este problema. 
habría que plantearse críticamente en el estadio actual de la investigación del II milenio a.n.e. en el suroeste es el de los indicadores arqueográficos que se han venido utilizando para definir la Edad del Bronce a efectos de registro habitacional.

Desde sus comienzos en el siglo XIX, y por razones cuya exposición excedería el propósito de este trabajo - cf. discusión en (García Sanjuán, 1992) - el estudio de la Edad del Bronce en el suroeste de la Península Ibérica ha estado fuertemente sesgado hacia el registro funerario. Ello ha generado una gran dependencia del propio concepto arqueográfico de Edad del Bronce respecto del registro funerario, de manera que hasta hoy día han sido principalmente la presencia de enterramientos individuales junto con la aparición de ciertas formas cerámicas (fundamentalmente carenadas) procedentes de contextos funerarios los criterios utilizados de forma (implícitamente) estandarizada para identificar un asentamiento como de la Edad del Bronce.

La constatación de la ausencia de hábitats con items cerámicos asociados que en su conjunto se pudieran considerar característicos de la Edad del Bronce, ya incluso desde que a mediados de los $1970 \mathrm{H}$. Schubart (1975) sistematizará su periodización arqueográfica del II milenio a.n.e. en el suroeste sobre la base del registro funerario, ha constituido uno de los fenómenos recurrentes de la investigación de la Edad del Bronce en el suroeste peninsular, especialmente en el sur de Portugal, donde literalmente se desconocen los asentamientos posteriores a $c .1700$ a.n.e. y anteriores a $c$. 1100 a.n.e. - cf. discusiones recientes de esta cuestión en, por ejemplo (V. Oliveira, 1990; Calado, 1993; Kunst, 1995).

Volviendo al caso específico de la Cuenca Media del Guadiana, el poblamiento del III milenio a.n.e. resulta mejor conocido gracias a los trabajos de la Pijotilla (Hurtado, 1986), un estudio general sobre los poblados (Enríquez, 1989;1990) y otras intervenciones prospectivas, las cuales, en su mayoría, han venido identificando culturalmente los yacimientos atendiendo a fósiles directores como platos, cerámica campaniforme u otros. De esta forma se ha dado a conocer una gran proporción de asentamientos adscritos al Calcolítico, mientras que resultaban casi totalmente desconocidos los correspondientes a la Edad del Bronce.

Las excavaciones de Palacio Quemado (Hurtado-Enríquez, 1991) han venido a plantear el problema de la cronología de estos yacimientos considerados del III milenio a.n.e., ya que en su segunda fase de ocupación (Edad del Bronce), el conjunto de items reflejaba sólo ligerísimas diferencias con la fase precedente (Edad del Cobre). Esta segunda fase de ocupación de Palacio Quemado está fechada en el siglo XVII por C-14 (1620 a.n.e.) y en sus inmediaciones existen enterramientos individuales. En el contexto de la Cuenca Media del Guadiana, Palacio Quemado no constituye un caso aislado a este respecto, puesto que el poblado de Los Cortinales (Gil Mascarell-Rodríguez, 1985) presenta una problemática similar (hábitat con materiales de superficie formalmente calcolíticos asociado a una necrópolis de cistas). En el caso concreto de Guadajira y La Pijotilla, de nuevo se observa que en su entorno general no existen hábitats donde se registren artefactos cerámicos semejantes a los de las estructuras funerarias.

En lo que se refiere a la Cuenca Media del Guadiana es pues necesario comenzar a asumir la pervivencia de los asentamientos de raíz calcolítica hasta una fecha tan avanzada en el II milenio a.n.e. como es, al menos la de c. 1600 a.n.e. cuando se ha extendido ya la individualización del espacio funerario. En La Pijotilla, la evolución conceptual desde la cámara funeraria colectiva hacia la cámara individual no parece venir acompañada de alteraciones sustanciales en el repertorio artefactual empleado en el espacio de habitación, producción y consumo.

Otras evidencias en favor de esta hipótesis arqueográfica para explicar el tradicional problema de la ausencia de hábitats fechados entre $c .1700$ y 1100 a.n.e. en el suroeste las proporciona el registro del II milenio a.n.e. en la Sierra Norte de Huelva, es decir la comarca limítrofe por el sur de la Cuenca Media del Guadiana. La comparación de la distribución de medios de producción cerámicos utilizados en la primera fase de ocupación del hábitat de El Trastejón (Zufre-Huelva), fechada por C-14 entre $c .1600$ y 1100 a.n.e., con la distribución de esas mismas categorías en los enterramientos individuales del suroeste sugiere que, precisamente, 
aquellas categorías más frecuentes en los contextos funerarios son las más infrecuentes en el asentamiento y viceversa (Hurtado-García Sanjuán, 1994). Este hecho sugiere precisamente que intentar identificar los hábitats de la Edad del Bronce a partir de formas de recipientes cerámicos habituales en los enterramientos individuales ha podido ser un serio error. Por otra parte, la necrópolis de enterramientos en cista de La Traviesa (Almadén de la Plata, Sevilla), fechada por C-14 en el siglo XVI a.n.e. (siglo XVIII calibrada la datación) - cf. (García Sanjuán, e.p.) se encuentra asociada a un hábitat donde los restos de útiles cerámicos recogidos presentan más similitudes formales con los de asentamientos del III milenio a.n.e. que con los de los propios enterramientos.

Arqueográficamente, la transición entre la Edad del Cobre y la Edad del Bronce en el suroeste peninsular se ha leido más en función del registro funerario que del registro habitacional, lo que ha supuesto una dificultad extra a la hora de identificar cronológicamente los yacimientos sólo por prospecciones superficiales. Es probable que algunos de los poblados considerados calcolíticos y próximos a los enterramientos en cista existentes en la provincia de Badajoz (y en el sur de Portugal) correspondan cronológicamente a la primera mitad del II milenio a.n.e. Tan solo la acumulación de dataciones de radiocarbono bien contextualizadas procedentes de hábitats excavados, permitirá en el futuro contrastar esta hipótesis 9 .

Ahora bien, aún teniendo en cuenta la escasez de evidencias empíricas, parece claro que los asentamientos de la primera mitad del segundo milenio a.n.e. en la Cuenca Media del Guadiana responden a dos patrones de ocupación.

Por una parte, un patrón que mantiene básicamente el esquema de las comunidades de la Edad del Cobre. La ubicación de asentamientos como La Pijotilla, Palacio Quemado y La Palacina, fortificados y situados en llano o en cotas poco elevadas tiene un carácter defensivo que habría que poner en relación directa con la función que cumplen como línea de control del territorio según la hipótesis planteada en un reciente trabajo sobre la dinámica cultural de la Cuenca Media del Guadiana (Hurtado, e.p.). De acuerdo con ella La Pijotilla es un gran asentamiento constituido como centro nuclear que controla un territorio situado en parte de la actual comarca de Tierra de Barros delimitado naturalmente al norte y oeste por el río Guadiana y al sur por las estribaciones de Sierra Morena y que en el sector oriental sitúa una línea de poblados amurallados dispuesta de norte a sur que lo protegen por la zona de mayor accesibilidad (fig. 23). La existencia de enterramientos individuales bien constatada en La Pijotilla, la aparición de artefactos de topología avanzada en La Pijotilla y Palacio Quemado, junto a la datación absoluta c. 1620 en éste último inducen a pensar que el modelo territorial se mantuvo hasta mediados del II milenio a.n.e. desapareciendo en ese momento no solo la estructura organizativa sino todos los poblados calcolíticos del territorio de Tierra de Barros. A partir de esa fecha se consolidan los asentamientos como Castillo de Alange, en cuya fase Solana IIB se construye una muralla datada por radiocarbono en 1570 a.n.e.

Por otra parte un patrón de nueva fundación en cuya ubicación se manifiesta una tendencia a elegir lugares elevados, estratégicos y sin defensas, entre los que se encontrarían el Cerro de San Cristóbal en Badajoz, el Castillo de Alange y quizás el (¿desaparecido?) poblado de Guadajira.

Ambos tipos de asentamiento pueden ser funcionalmente complementarios y operar dentro de un esquema territorial definido, aunque este extremo no podrá ser analizado en profundidad hasta que se desarrolle un Programa de Investigación Sistemática del poblamiento del II milenio a.n.e. en la Cuenca Media del Guadiana.

9. Por otra parte, una relectura calibrada de las (escasas) dataciones de radiocarbono procedentes de contextos funerarios sugiere que los enterramientos en cista que constituyen uno de los demarcadores arqueográficos básicos de la Edad del Bronce en el suroeste no comienzan a ser utilizados alrededor del siglo XVI como se viene asumiendo en general, sino probablemente ya en el siglo XVIII, con lo que se incrementará su convivencia con las formas cerámicas que suelen ser utilizadas en las cartas arqueológicas para identificar los poblados calcolíticos. 


\section{IV.c. La cronología de los enterramientos de Guadajira}

Las dataciones de radiocarbono existentes en la actualidad (Tabla 3) sugieren que los enterramientos colectivos más tardíos según dataciones de radiocarbono alcanzan hasta el siglo XIX a.n.e. En la Cuenca Media

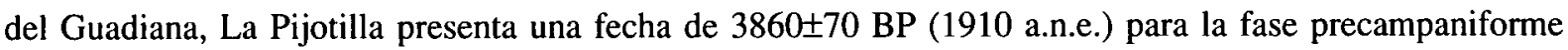
(Hurtado, 1981), mientras que en el tholos de Huerta Montero, existe una datación de 3720 100 BP (1770 a.n.e.) para una segunda ocupación de la tumba (Blasco-Ortiz, 1991) ${ }^{10}$.

Por otra parte, la extensión de los enterramientos individuales frente a los colectivos en el suroeste se ha verificado al menos en el siglo XVI a.n.e. (XVIII A.N.E.). Los más antiguos enterramientos individuales del II milenio a.n.e. fechados por radiocarbono hasta la fecha son los de Setefilla (Aubet et alii, 1983), La Traviesa (García Sanjuán, e.p.) y Herdade do Pomar (Barceló, 1991; Soares-Tavares, 1995), pero ninguno de ellos se encuentra situado en la Cuenca Media del Guadiana. Correspondientes a la segunda mitad del segundo milenio son los de Herdade de Belmeque (Monge, 1994), en la margen derecha de la Cuenca Media del río Guadiana y Las Minitas, en la Tierra de Barros (Pavón et alii, e.p.).

Considerando exclusivamente a las dataciones de radiocarbono disponibles para el suroeste, y asumiendo que los enterramientos de Guadajira se inscriben en la transición desde el ritual de inhumación en cámaras colectivas hacia el ritual de inhumación en cámaras individuales, Guadajira podría ser fechada aproximadamente entre $c .1800$ y 1600 a.n.e., aunque la presencia del campaniforme inciso en la tumba 3 apuntaría mejor hacia $1800 / 1700$ a.n.e.

En lo que se refiere a los asentamientos, la continuidad de los hábitats calcolíticos hasta mediados del II milenio a.n.e se constata igualmente en algunos yacimientos de la Extremadura portuguesa, cuyo poblado mejor conocido, Zambujal, se mantiene aún a fines del XVII a.n.e. según muestran las analogías cerámicas con el poblado de Agroal, datado por radiocarbono en 1620 y 1610 a.n.e. (Kunst, 1995) al tiempo que se advierte un progresivo abandono o recesión del área habitada por los poblados de altura en favor de la ocupación de lugares abiertos (Parreira, 1995). En el Cerro del Berrueco (Cádiz) el estrato II, considerado de inicios de la Edad del Bronce, aportó una fecha de 1670 a.n.e. y se superpone a un nivel de ocupación de fines del Calcolítico o de transición al Bronce en el que aparecieron enterramientos individuales en fosa (EscacenaFrutos, 1986). También al s. XVII (1615 a.n.e.) corresponde el momento de fundación del poblado de la Edad del Bronce del Trastejón, situado en la Sierra de Huelva, una fecha en perfecta consonancia con el repertorio cultural del estrato XIV de Setefilla y la anteriormente citada del Castillo de Alange para la fase de Bronce Pleno (Pavón, 1995).

\section{GUADAJIRA EN EL PROCESO DE JERARQUIZACIÓN DE LAS FORMACIONES SOCIALES DE LA EDAD DEL COBRE EN EL SUROESTE PENINSULAR}

A lo largo de este artículo se ha realizado una contextualización del registro empírico obtenido en la necrópolis de Guadajira en el más amplio marco de la transición a la Edad del Bronce en la Cuenca Media del

10. La datación radiocarbónica de la fase más antigua de Huerta Montero proporcionó una fecha de 2700 a.n.e, mientras que en la segunda y más reciente se obtuvieron dos dataciones, 2270 y 1770 a.n.e (Blasco-Ortiz, 1991). Estas dataciones plantean algunos problemas, dadas las diferencias cronológicas existentes entre la primera y segunda fase e incluso la larga duración aparente de esta última, aunque el escueto informe publicado hasta ahora no permite profundizar en el análisis de esta tumba en el contexto cultural de la región. 
Guadiana y, por extensión, en el suroeste peninsular. De acuerdo con la discusión realizada en el epígrafe anterior, los enterramientos de Guadajira se insertan en un periodo de transición entre la Edad del Cobre y la Edad del Bronce que se situaría aproximadamente entre $c .1800$ y 1600 a.n.e.

Ahora bien ¿como puede interpretarse desde un punto de vista procesual e histórico, y no puramente arqueográfico, la peculiar naturaleza de los tres enterramientos de Guadajira, conceptualmente situados a medio camino entre los enterramientos colectivos de la Edad del Cobre y los enterramientos individuales de la Edad del Bronce? Aunque este artículo tiene un propósito más descriptivo que interpretativo, en esta última sección se esboza el marco procesual en el que los rasgos específicos de una localización funeraria de las características y cronología de Guadajira podrían adquirir sentido ${ }^{11}$.

Según las evidencias osteológicas descritas anteriormente, los enterramientos de Guadajira contenían aproximadamente entre 5 y 15 individuos. El mal estado en que se encontraban los enterramientos cuando comenzó su exploración científica no permite asegurar con precisión el número de individuos inhumado, pero lo que sí se puede asumir con total seguridad es que, constituyendo enterramientos colectivos, en ningún caso se asemejan a enterramientos colectivos en tholoi como los de La Pijotilla o Huerta Montero, en los que fueron inhumadas más de un centenar de personas.

Un presupuesto generalmente aceptado en relación con estos enterramientos colectivos de la Edad del Cobre es que contienen unidades familiares extensas (clanes). Asumiendo que tal presupuesto es correcto, a la espera de que sea objeto de una contrastación empírica mediante el estudio de las posibles relaciones de parentesco biológico entre los inhumados (por ejemplo mediante análisis del ADN de los restos óseos), y con independencia de cuál sea la naturaleza de esas unidades familiares (que puede no ser la misma en todos los casos puesto que la desviación en el número de inhumados en diferentes enterramientos es con frecuencia amplia), una característica recurrente en los enterramientos de este periodo es que se constata una tendencia a que, dentro de los grupos de parentesco, la distribución de los ajuares tiende a ser mas bien homogénea y simétrica, del mismo modo que la complejidad constructiva del contenedor funerario es común a todos los miembros del grupo parental y del mismo modo que la ubicación en el espacio del contenedor funerario es la misma para todos los miembros de la unidad parental.

No obstante, si bien es cierto que los enterramientos colectivos de este periodo muestran una acusada tendencia hacia la indiferenciación intraparental en esa expresión ideológica tan trascendental que supone el rito funerario, existen algunas evidencias puntuales que sugieren que está ya en marcha un proceso de paulatina acentuación del liderazgo intraclánico. Así, dentro de la cámara de los tholoi de la necrópolis de Alcalar se disponen espacios reservados para ciertos individuos (S. Oliveira, 1990), mientras que en el enterramiento 3 de La Pijotilla se ha identificado un individuo cuyo equipo de ajuar se distingue ligeramente de la norma

11. En conjunto, el proceso general de jerarquización y estratificación de las relaciones sociales de producción dentro de las formaciones sociales del suroeste peninsular entre c. 2500 y 750 a.n.e. requiere un análisis mucho más amplio del que puede ser presentado aquí. Para empezar, este proceso sólo puede ser analizado mediante una preliminar sistematización teórica y conceptual a la que siga una sistematización de los indicadores arqueológicos de la estratificación social, tanto del registro funerario como del registro habitacional, lo cual, a su vez, sólo puede verificarse atendiendo a los procesos de transición hacia la complejidad social que tienen lugar en el continente europeo y en el próximo oriente en las edades del Cobre y del Bronce. (A este respecto, la discusión aquí ofrecida es muy limitada: por una parte se centra únicamente en los indicadores del registro funerario y no en los del registro habitacional y, segundo, el referente más amplio en el que se inserta el problema original tratado - los enterramientos de Guadajira - es tan solo el del cuadrante suroccidental de la Península Ibérica ya que no se ha procedido a insertar el registro de esta necrópolis en el contexto de la Edad del Bronce en la Península Ibérica o en Europa). Una aproximación a este problema está siendo en la actualidad desarrollada por uno de los firmantes de este trabajo como parte de una Tesis Doctoral. 
predominante por la naturaleza y cantidad de los items (Hurtado, e.p.). Ello sugiere que el estatus social de ciertos individuos comienza a diferenciarse lo suficiente dentro de la comunidad como para que ello se refleje ideológicamente de una forma abierta en el ritual funerario; con todo, la cámara funeraria colectiva sigue constituyendo el espacio común de enterramiento por encima de las diferencias y desigualdades sociales. Dicho en otras palabras: la ideología comunalista se sobrepone netamente a la incipiente función de liderazgo que parecen estar asumiendo algunos individuos.

En la necrópolis de Guadajira, las malas condiciones de conservación en la Tumba 1 y en la Tumba 2 imposibilitan una valoración de la distribución de los ajuares entre los diferentes individuos inhumados, pero en el caso de la Tumba 3, mejor preservada, no se observó ninguna distinción especial de un individuo mediante un ajuar especial: la distribución del ajuar funerario mantiene un perfil simétrico. Los enterramientos de Guadajira parecen por tanto albergar unidades familiares menos extensas que los enterramientos (super)colectivos del tipo de La Pijotilla o Huerta Montero, pero el principio de indiferenciación simbólicoideológica se mantiene.

Como se ha señalado anteriormente, a partir de c. 1700 a.n.e. se produce en la Cuenca Media del Guadiana y en el suroeste peninsular una fuerte implantación de la inhumación en cámaras individuales y un retroceso proporcional de las inhumaciones en cámaras colectivas; los enterramientos colectivos no desaparecen, pero pasan a constituir una minoría frente a la extensión de los enterramientos individuales.

La regla antes predominante de concentrar los individuos de una misma unidad familiar dentro de un mismo microespacio funerario (cámara colectiva) - cuya complejidad constructiva era evidentemente la misma para todos los componentes de la unidad parental - empieza a relajarse en favor de una tendencia al individualismo. La tendencia incipiente observada en ciertos sepulcros colectivos como los de Alcalar o en ciertas cuevas artificales, donde dentro del espacio funerario común, algunos personajes presentaban una cámara relativamente individualizada o un ajuar relativamente personalizado, se hace universal ahora, de forma que todos los integrantes de la unidad parental son enterrados en cámaras unipersonales (generalmente cistas), situadas a escasa distancia pero independientes. En determinadas ocasiones, la posición del líder es enfatizada mediante la fabricación de contenedores funerarios especiales, más visibles y monumentales: en necrópolis como Atalaia, Provença, La Traviesa o Alfarrobeira este líder ocupa una posición central respecto a los demás miembros de la unidad parental, y es el único que posee una estructura anular/tumular completa propia. En otras muchas necrópolis de enterramientos individuales, la presencia de estructuras constructivas especiales que señalen un posible líder comunitario no ha sido constatada, quizás porque los rasgos que distinguieron su enterramiento de los demás sean indocumentables arqueológicamente.

Si se analiza la relación entre las diferentes categorías constructivas y artefactuales en necrópolis como Atalaia y Provença (García Sanjuán, 1994) no parece existir asociación entre los enterramientos centrales y los items sociotécnicos de mayor prestigio (metálicos), para empezar por la escasez manifiesta de los mismos.

En resumen, a partir del examen de los indicadores funerarios es posible inferir la existencia a partir de $c$. 1700 a.n.e. de una tendencia disgregadora muy fuerte del patrón de relaciones de parentesco observado en las formaciones sociales de finales del III milenio a.n.e. y comienzos del II milenio a.n.e. (los miembros de una familia no ocupan la misma cámara mortuoria que sus antecesores y contemporáneos, sino que se entierran en cámaras individuales) tanto en la Cuenca Media del Guadiana como en el suroeste en su conjunto. Asimismo, se refuerza el liderazgo intraclánico, de tal forma que pasa a ser expresado de una forma explícita en el ámbito de las costumbres funerarias, rompiéndose la tendencia al comunalismo indiferenciado de la fase precedente (c. 2500-1700 a.n.e.).

Dicho a grandes rasgos, la comunidad que ocupó el cerro de Guadajira hacia $c .1800-1600$ a.n.e. se encontraba inserta en un proceso de agudización de la jerarquización intragrupal caracterizado por estas dos premisas: disgregación de las cohesión simbólica que las grandes unidades de parentesco muestran en la etapa prece- 
dente (c. 1500-1700 a.n.e.), y fortalecimiento de las funciones de liderazgo de ciertos individuos dentro de las comunidades.

\section{BIBLIOGRAFÍA}

AMORES, F. (1982): Carta arqueológica de los Alcores (Sevilla). Sevilla. Diputación Provincial

AUBET, M.E.; SERNA, M.R. (1981): "Una sepultura de la Edad del Bronce en la Mesa de Setefilla (Lora del Río, Sevilla)." Madrider Mitteilungen. Num 22. Madrid.

AUBET, M.E.; SERNA, M.R.; ESCACENA, J.L.; RUIZ DELGADO, M.M. (1983): La Mesa de Setefilla (Lora del Río, Sevilla). Campaña de 1979. EAE num 122. Madrid.

BARANDIARÁN,I. (1978): "La Atalayuela: fosa de inhumación colectiva del Eneolítico en el Ebro Medio." Príncipe de Viana num 152-153. Pamplona

BELÉN, M.; AMO, M. (1985): "Investigaciones sobre el megalitismo en la provincia de Huelva. Los sepulcros de Las Plazuelas y El Tejar." Huelva Arqueológica num 7. Huelva. Diputación Provincial.

BLASCO, F.; ORTIZ (1991): "Trabajos arqueológicos en Huerta Montero (Almendralejo, Badajoz)." Actas de las I Jornadas de Prehistoria y Arqueología en Extremadura (1986-1990). Extremadura Arqueológica II. Mérida. Junta de Extremadura

BRABANT, H. (1967): "Paleoestomathology". En SANDISON, M-BROTHWELL, H.(eds): Diseases in Antiquity. Springfield. Illinois

BUDD, P. (1991): "Eneolithic arsenical copper: heath treatment and the metallographic interpretation of manufacturing processes. En PERNICKA, E; WAGNER, G.A.(eds.): Archaeometry'90

CALADO, M. (1993): Carta arqueológica do Alandroal. Alandroal. Câmara Municipal

CALERO, J.A. et alii (1988): "Cuarta y quinta campaña de excavaciones arqueológicas en Alange (19871988)." XVII Coloquios Históricos de Extremadura. Trujillo.

CERDAN, C.; LEISNER, G.; LEISNER, V. (1952): "Los sepulcros megalíticos de Huelva". Informes y Memorias num 26. Madrid

CHIMENOS, E. (1990): Estudio paleoestomatológico de poblaciones prehistóricas de Catalunya. Zaragoza.

CONTRERAS, F.; CAPEL, J.; ESQUIVEL, J.A.; MOLINA, F.; TORRE, F. (1988): "Los ajuares cerámicos de la necrópolis argárica de la Cuesta del Negro (Purullena, Granada). Avance al estudio analítico y estadístico." Cuadernos de Prehistoria de la Universidad de Granada num 12-13. Granada. Publicaciones de la Universidad

DELIBES, G. (1977): El Vaso Campaniforme en la Meseta Norte española. Valladolid.

DELIBES, G.; FERNANDEZ MIRANDA, M.; FERNÁNDEZ POSSE, M.D.; MARTIN, C.; ROVIRA, S.; SANZ, M. (1989): “Almizaraque (Almeria): Mineria y metalurgia calcolíticas en el sureste de la Peninsula Ibérica”. En DOMERGUE, C.(ed.): Mineria y metalurgia en las antiguas Civilizaciones Mediterráneas y Europeas vol I. Ministerio de Cultura. Madrid.

ENRÍQUEZ, J.J. (1989): Los poblados calcolíticos de la Cuenca Media del Guadiana. Aproximación al estudio de los comprendidos entre las vegas altas y bajas del Guadiana (la comarca de Mérida). Madrid. Publicaciones de la Universidad Complutense

- (1990): El Calcolítico o Edad del Cobre de la cuenca extremeña del Guadiana: los poblados. Publicaciones del Museo Arqueológico Provincial de Badajoz num 2. Badajoz

— DOMINGUEZ, M.C. (1984): "Yacimientos pre y protohistóricos de Badajoz y sus alrededores". Revista de Estudios Extremeños num 48. Badajoz

- JIMENEZ, E. (1989): Las tierras de Mérida antes de los romanos. Prehistoria de la comarca de Mérida. Mérida. 
— HURTADO, V. (1986): "Prehistoria y Protohistoria." En AAVV: Historia de la Baja Extremadura. Badajoz.

ESCACENA, J.L.; FRUTOS, G. de (1981): "Enterramientos de la Edad del Bronce en el Cerro del Berrueco (Medina Sidonia, Cádiz)". Pyrenae. Num 17-18. Barcelona

ESTÉVEZ, J.; LULL, V. (1984): "Aplicación de la biometría elemental al análisis cerámico (I)." Actas de las Primeras Jornadas de Metodología de investigación prehistórica (Soria, 1981). Madrid. Ministerio de Cultura

FERNÁNDEZ CARO, J.J. (1992): Carta arqueológica del término de Fuentes de Andalucía. Fuentes de Andalucía. Excmo. Ayto.

FERNÁNDEZ GÓMEZ, F.; RUIZ, D. (1978): "El tholos del Cerro de la Cabeza en Valencina de la Concepción (Sevilla." Trabajos de Prehistoria num 35. Madrid. CSIC

GARCÍA SANJUAN, L. (1992): La variabilidad de los enterramientos individuales en el Suroeste de la Península Ibérica (1500-1100 a.C.): una aproximación estadística. Sevilla. Tesis de Licenciatura inédita

- (1994): "Registro funerario y relaciones sociales en el SO (1500-1100 a.n.e.): indicadores estadísticos preliminares.” En CAMPOS, J.; PÉREZ, J.A.; GÓMEZ, F.(eds):Arqueología en el entorno del Bajo Guadiana. Actas del Encuentro Internacional de Arqueología del Suroeste (Huelva, Marzo 1993). Huelva

(e.p.) "Segunda intervención de urgencia en el yacimiento de la Edad del Bronce de La Traviesa (Almadén de la Plata, Sevilla)." Anuario arqueológico de Andalucíal1993. Sevilla. Junta de Andalucía

GÁRCÍA SANJUAN, L.; VARGAS, M.A. e.p. "Intervención de urgencia en el yacimiento de la Edad del Bronce de La Traviesa (Almadén de la Plata, Sevilla)." Anuario arqueológico de Andalucíal1992. Sevilla. Junta de Andalucía

GIL MASCARELL, M.; RODRÍGUEZ DÍAZ, A. (1987): "El yacimiento calcolítico de Los Cortinales en Villafranca de los Barros (Badajoz)." Homenaje al profesor D. Fletcher. Archivo de Prehistoria Levantina num 17. Valencia

GIL MASCARELL, M.; RODRÍGUEZ DÍAZ, A.; ENRÍQUEZ, J.J. (1986): "Enterramientos en cista de la Edad del Bronce en la Baja Extremadura." Saguntum numero 20. Valencia. Publicaciones de la Universidad

GUIJO, J.M.; PECERO, J.C. (1995): Estudio de los restos antropológicos de Guadajira, Badajoz. (Informe inédito).

HURTADO, V. (1984): El yacimiento de la Pijotilla (Badajoz). Estudio de relaciones culturales. Tesis doctoral inédita. Sevilla

- (1985): "Excavacion de una sepultura semicircular de la Edad del Bronce en Guadajira." Homenaje a Cánovas Pesini. Badajoz

— (1993): “Análisis y definición de los procesos culturales del II milenio a.C. en el Suroeste peninsular." En CAMPOS, J.; NOCETE, F.(eds): Investigaciones arqueológicas en Andalucía 1985-1992. Huelva. Junta de Andalucía

- (e.p.): "The dynamics of occupation in the Middle Basin of the Guadiana between the fourth and second millenia B.C.): an interpretational hypothesis." Proceedings of the 1992 Theorical Archaeology Group Conference (Southampton, December 1992)

HURTADO, V.; AMORES, F. (1982): "Relaciones culturales entre el sudeste francés y la Pijotilla (Badajoz) en el calcolítico: las pastillas repujadas y el campaniforme cordado". Habis num 13. Sevilla. Publicaciones de la Universidad

— ENRÍQUEZ, J.J. (1991): "Excavaciones en Palacio Quemado (Alange, Badajoz). Informe Preliminar." Actas de las I Jornadas de Prehistoria y Arqueología en Extremadura (1986-1990). Extremadura Arqueológica num 2. Mérida

— GARCÍA SANJUAN, L. (1994): “Areas funcionales en el poblado de la Edad del Bronce de El Trastejón (Zufre, Huelva).” En CAMPOS, J.; PÉREZ, J.A.; GÓMEZ, F.(eds)): Arqueología en el entorno del Bajo 
Guadiana. Actas del I encuentro de Arqueología del Suroeste de la Península Ibérica (Huelva, Marzo 1993). Huelva. Junta de Andalucía

- GARCÍA SANJUAN, L.; MONDÉJAR, P. (1994): "Prospección en la Sierra de Huelva y estudio de materiales del yacimiento de El Trastejón. Campaña de 1991." Anuario arqueológico de Andalucíal1991. Sevilla. Junta de Andalucía

KUNST, M. (1995): “A Idade do Bronze na Estremadura” En AAVV: A Idade do Bronze em Portugal. Discursos de poder. Lisboa Museu Nacional de Arqueología

LULL, V. (1983): La "cultura" de El Argar. Un modelo para el estudio de las formaciones económicosociales prehistóricas. Madrid. Akal

MARQUÉS, T.(ed) (1992): Carta arqueológica de Portugal (Portimao, Lagoa, Silves. Albufeira, Loulé, Sao Brás de Alportel). Lisboa. Instituto Portugués do Patrimonio.

MARTÍN CONSUEGRA, E. (1995): Informe polínico de los yacimientos de Guadajira (Badajoz) y La Traviesa (Sevilla). (Inédito).

MONGE, A. (1994): O Bronze do Sudoeste na margem esquerda do Guadiana. As necropoles do Concelho de Serpa." Actas das V Jornadas Arqueológicas (Lisboa, 1993). Lisboa. Asociaçao dos Arqueólogos Portugueses

MONTERO (1992a): Estudio arqueometalúrgico en el sudeste de la Peninsula Ibérica. Colección Tesis Doctorales, no 91-92. Madrid. Universidad Complutense

- (1992b): "La actividad metalúrgica en la Edad del Bronce del Sudeste de la Peninsula Ibérica: Tecnologia e interpretación cultural." Trabajos de Prehistoria num 49. Madrid. CSIC

OLIVEIRA, S. (1990): "Desenvolvimento da hierarquizaçao social e da metalurgia." En OLIVEIRA, V. et alii: Portugal das origens à romanizaçao. Lisboa. Presença

OLIVEIRA, V. (1990): "Complexificaçao das sociedades e sua inserçao numa vasta rede de intercambios." En OLIVEI RA, V. et alii: Portugal das origens à romanizaçao. Lisboa. Presença

ORIA, M. et alii (1990): El poblamiento antiguo en la Sierra Sur de Sevilla: zona de Montellano. Sevilla. Excmo. Ayto de Montellano

PARREIRA, R. (1995): “Aspectos da Idade do Bronze no Alentejo interior.” En AAVV: A Idade do Bronze em Portugal. Discursos de poder. Lisboa. Museu Nacional de Arqueología

PAÍS, J. (1994): "Restos vegetais provenientes do interior de vasos e de cistas da necrópole de Alfarrobeira." En VARELA GOMES, M.: A necrópole de Alfarrobeira (S. Bartolomeu de Messines) e a ldade do Bronze no Concelho de Silves. Silves. Museu Municipal de Arqueología

PAVÓN, I. (1994): Aproximación al estudio de la Edad del Bronce en la Cuenca Media del Guadiana: La Solana del Castillo de Alange (1987). Cáceres. Ed. El Broncense

- (1995a): "La Edad del Bronce". Extremadura Arqueológica num 4.

- (1995b): El tránsito del II al I milenio a.c. en las cuencas medias de los rios Tajo y Guadiana: la Edad del Bronce. Tesis doctoral inédita. Cáceres.

— GONZÁLEZ, J.L.; PLAZA, J.F. (e.p.): "Las Minitas (Almendralejo, Badajoz): una necrópolis de cistas del Bronce del Suroeste en la Tierra de Barros (Campaña de urgencia de (1994)." Norba num 13. Cáceres

POSAC, C. (1975): "Los Algarbes (Tarifa). Una necrópolis de la Edad del Bronce." Noticiario arqueológico hispánico num 4. Madrid

RIVERO, E.; VÁZQUEZ, M.C. (1988): "Un enterramiento del Horizonte Ferradeira en la provincia de Huelva." Actas de las II Jornadas del Patrimonio de la Sierra de Huelva (Cortegana, 1986). Huelva

RODRÍGUEZ DÍAZ, A. (1986): Arqueología de Tierra de Barros. Badajoz

ROVIRA, S.; MONTERO, I.; CONSUEGRA, S. (1992): "Archaeometallurgical study of Palmela arrow heads and other related types". En ANTONACCI, E.(ed.): Archeometallurgia. Ricerche e Prospettive. Bolonia. CLUEB

ROVIRA, S.; MONTERO, I. (1994): "Metalurgia campaniforme y de la Edad del Bronce en la comunidad de 
Madrid". En BLASCO, C.(ed): El Horizonte Campaniforme de la Región de Madrid en el centenario de Ciempozuelos. Madrid. UAM

RUIZ DELGADO, M.M. (1985): Carta arqueológica de la campiña sevillana. Zona SE I. Sevilla. Publicaciones Universidad

SCHUBART, H. (1973): “Tumbas megalíticas con enterramientos secundarios de la Edad del Bronce en Colada de Monte Nuevo de Olivenza." Actas del XII Congreso Nacional de Arqueología. Zaragoza

- (1975): Die Kultur der Bronzezeit im SW der Ibersichen Halbinsel. Madrider Forschungen num 9. Berlín

SOARES, J; TAVARES, C. (1995): “O Alentejo litoral no contexto da Idade do Bronze do sudoeste peninsular."'En AAVV: A Idade do Bronze em Portugal. Discursos de poder. Lisboa. Museu Nacional de Arqueología

STEVENSON, A.C.; HARRISON, R.J. (1992): “Ancient forests in Spain: a model for land-use and dry forest management in southwest Spain from 4000 BC to 1900 AD." Proceedings of the Prehistoric Society num. 58

TIPPING, R. (1994): "Ritual floral tributes in the Scottish Bronze Age. Palynological evidence." Journal of Archaeological Science vol 21 num 1. London. Academic Press

VARELA GOMES, M. (1994): A necrópole de Alfarrobeira (S. Bartolomeu de Messines) e a Idade do Bronze no Concelho de Silves. Silves. Museu Municipal de Arqueología. 

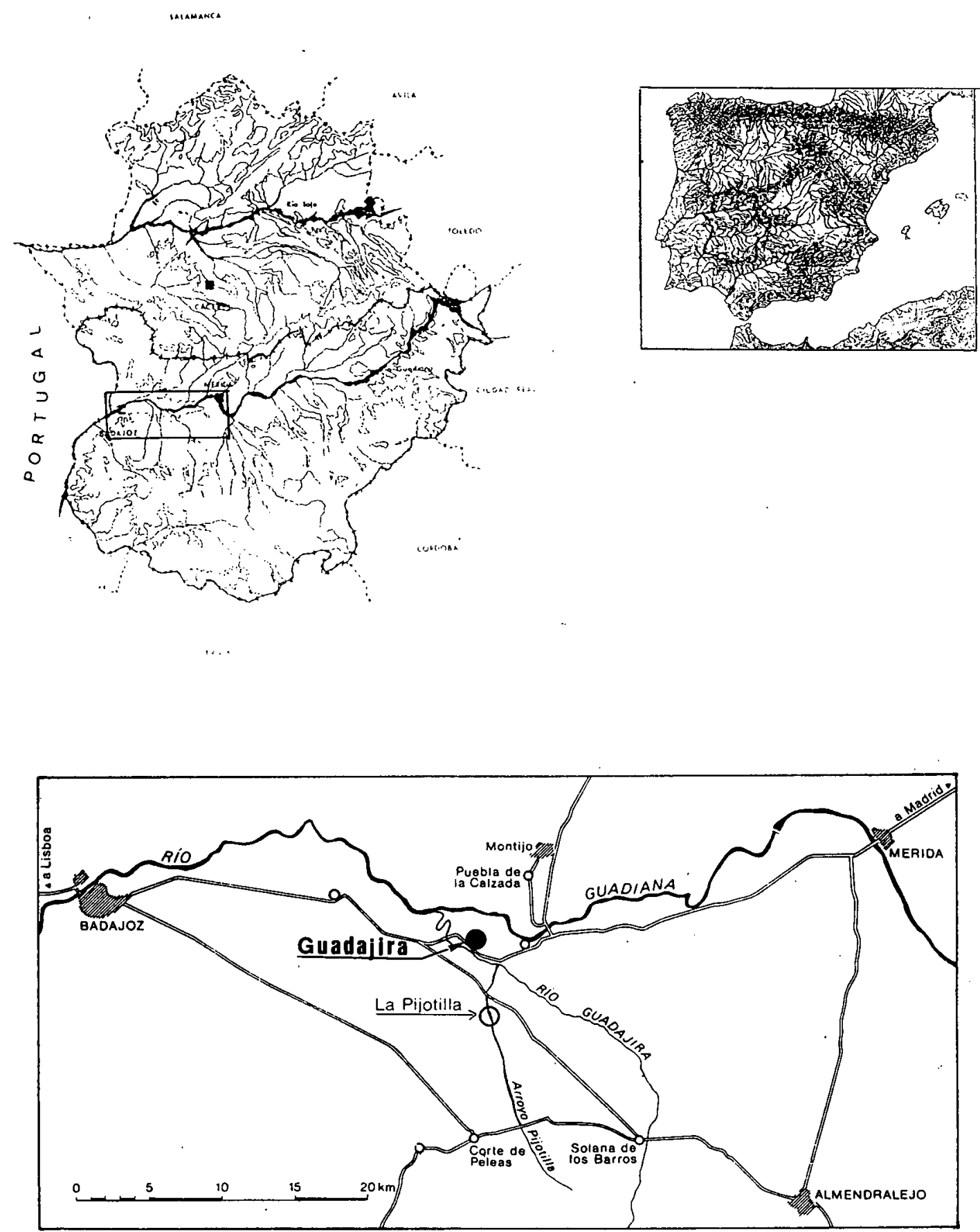

Fig. 1. Situación de la necrópolis de Guadajira. 


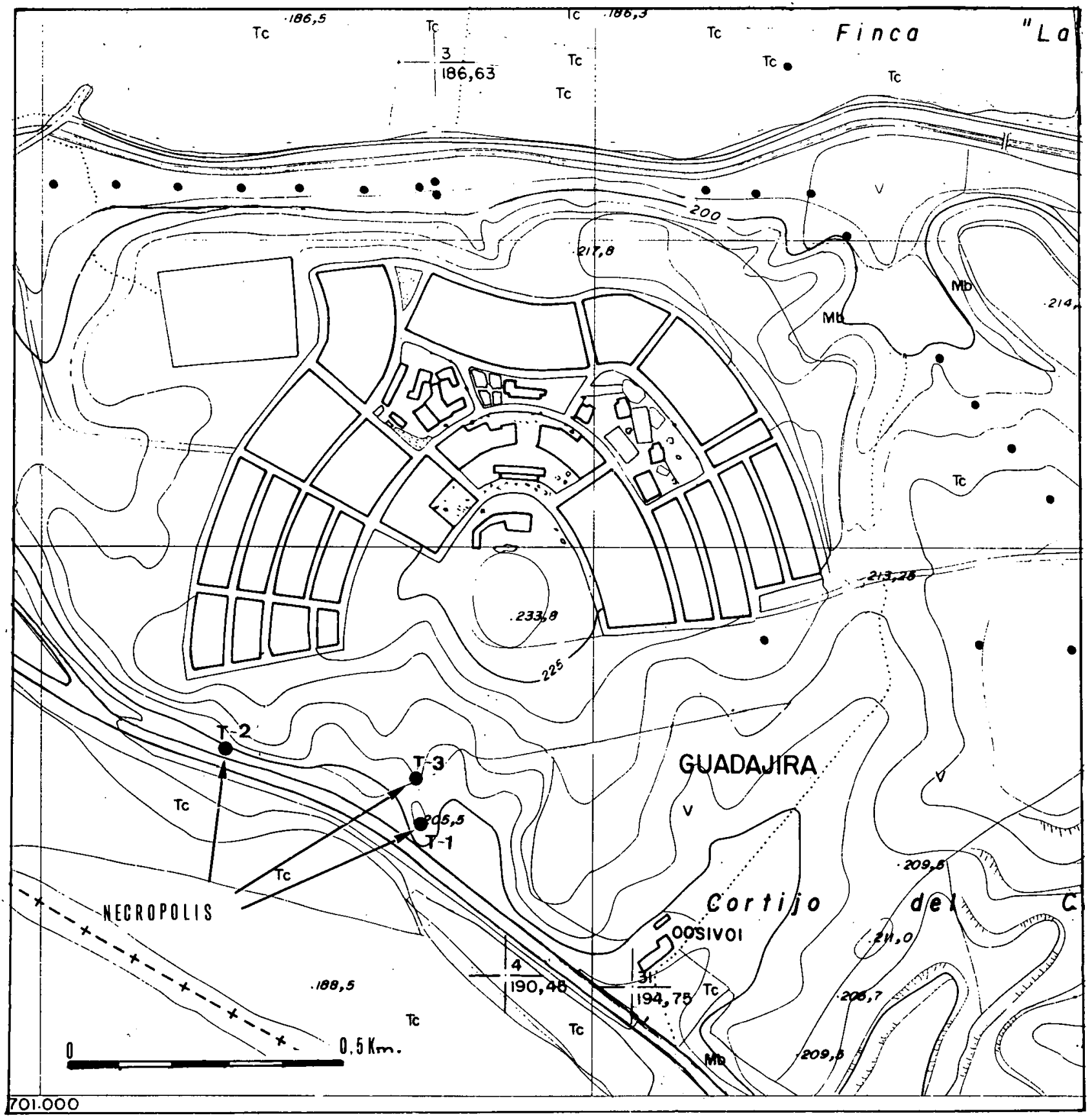

Fig. 2. Situación de los enterramientos. 


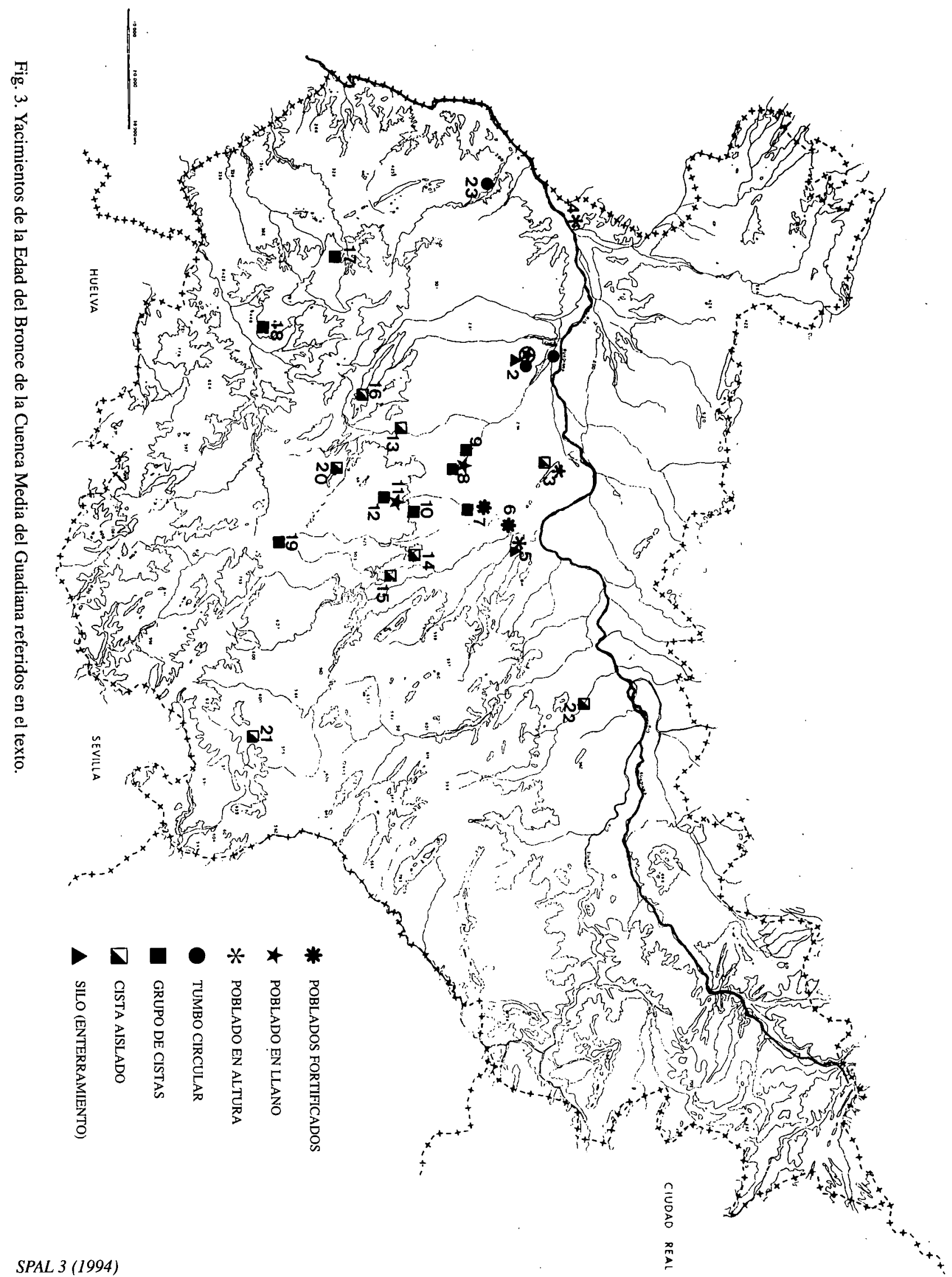




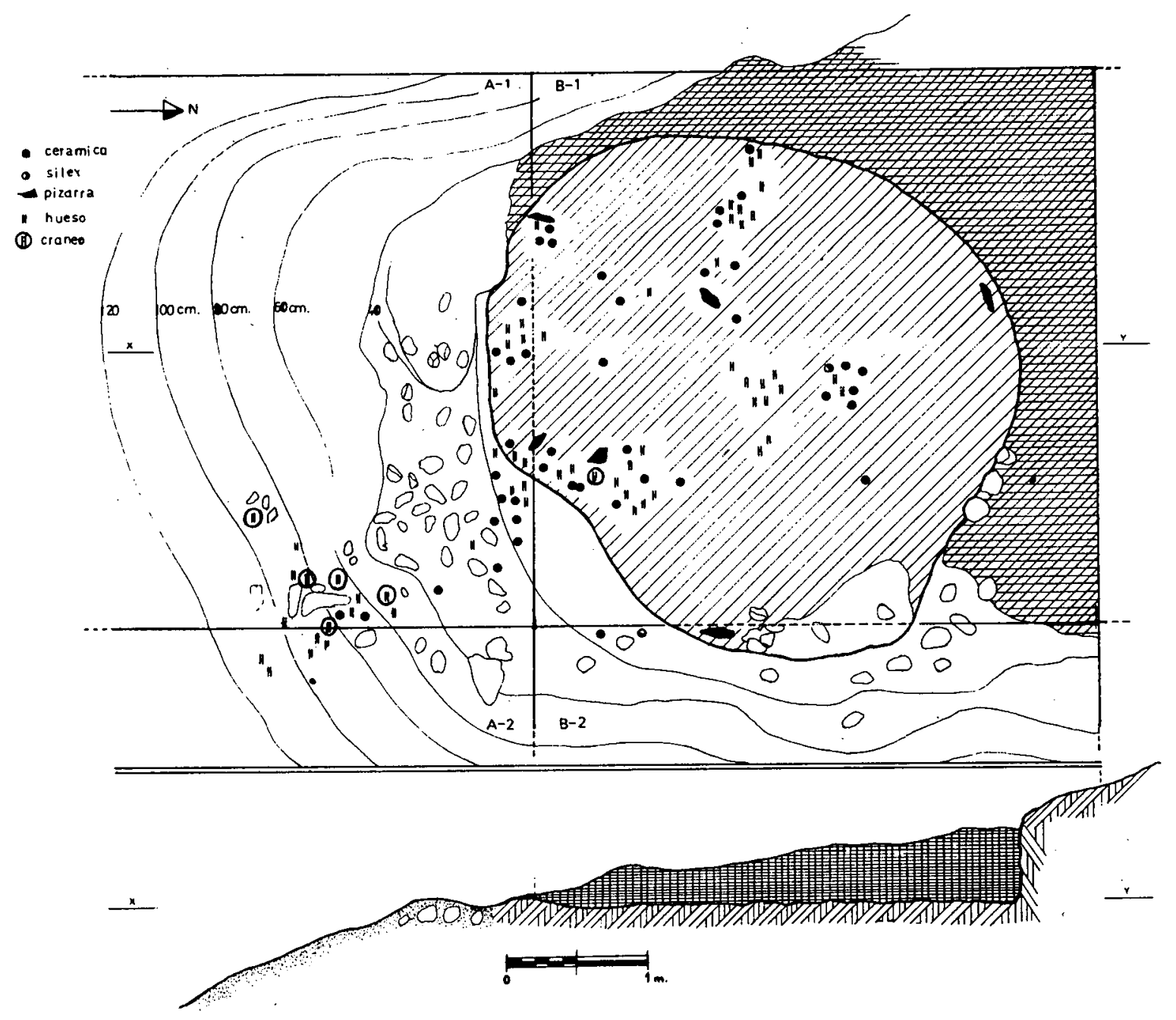

Fig. 4. Planta de la tumba 1 (según Hurtado, 1985). 

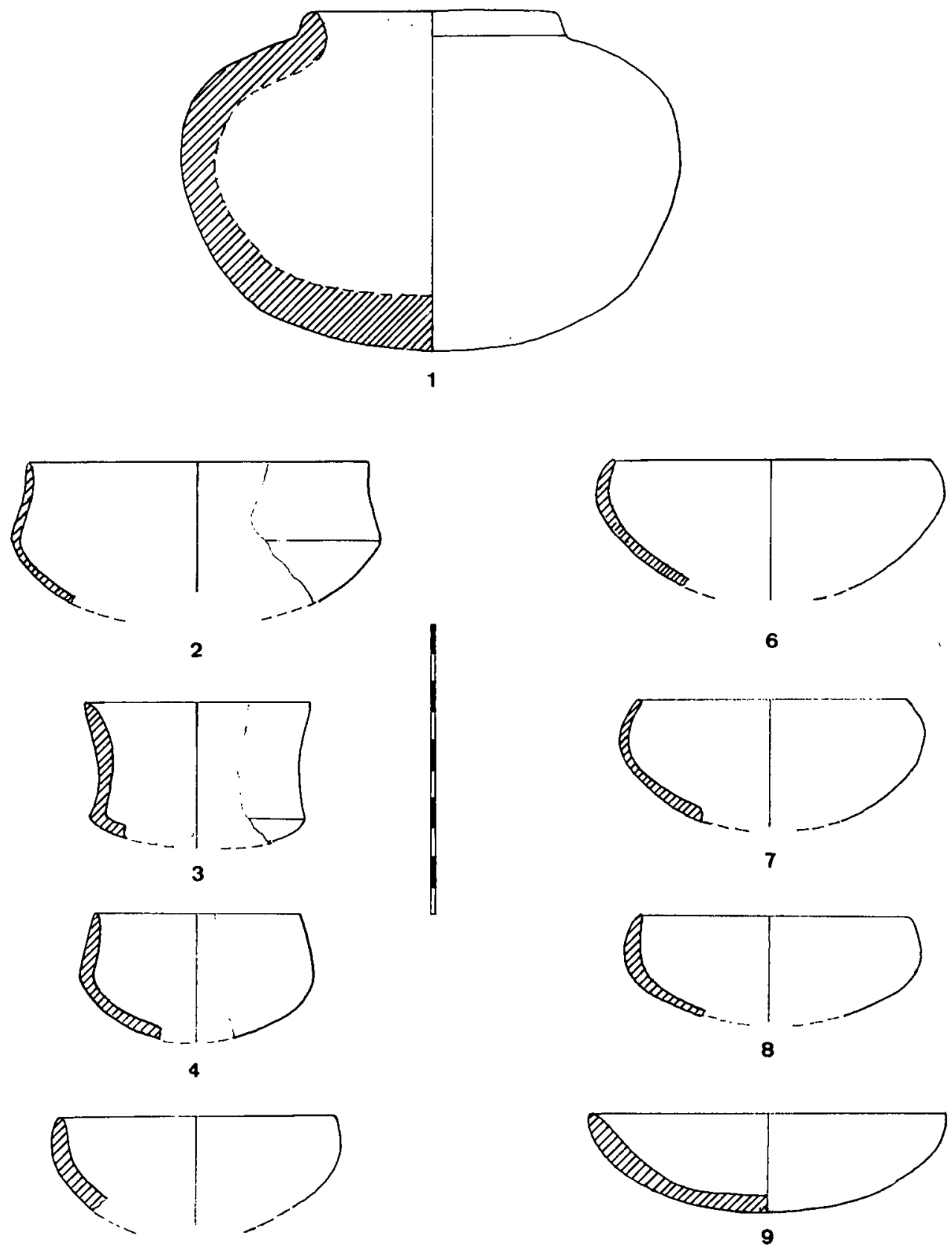

5

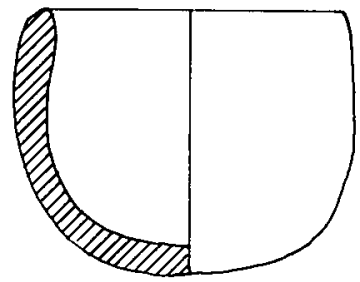

10

Fig. 5. Recipientes cerámicos de la tumba 1 (Colección Jerez). 

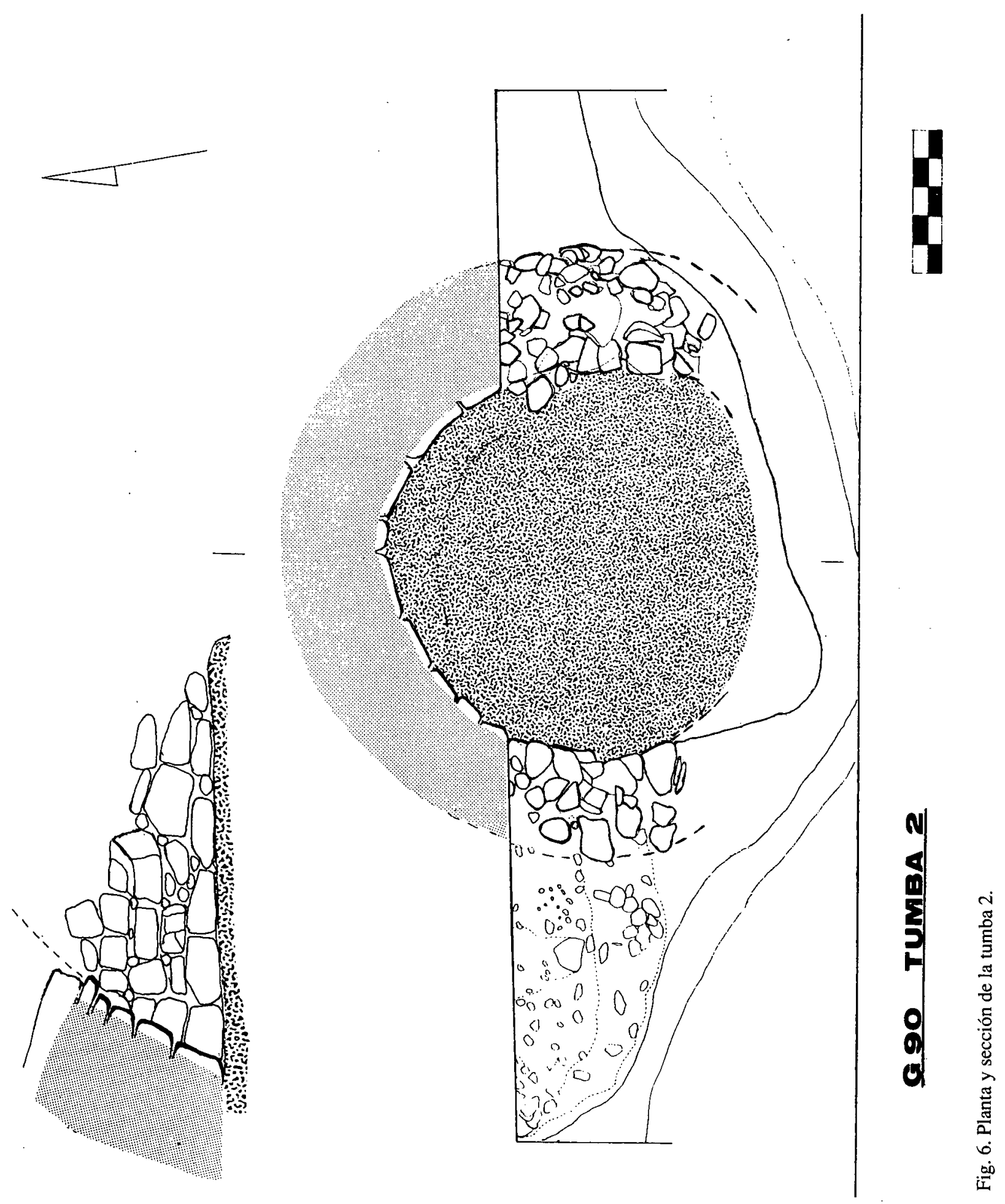

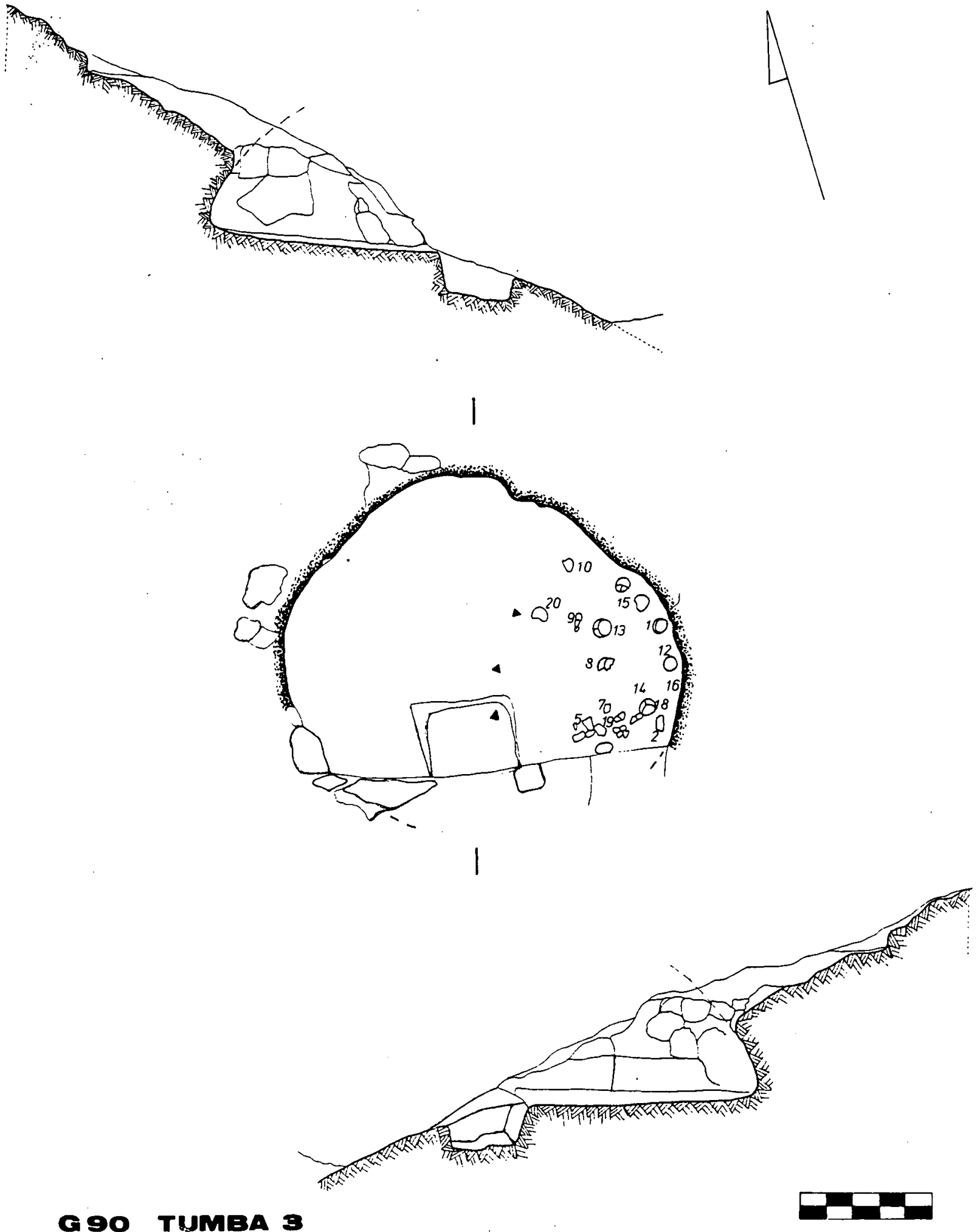

\section{G90 TNMEA 3}

Fig. 7. Sección oriental, planta y sección occidental de la tumba 3. 

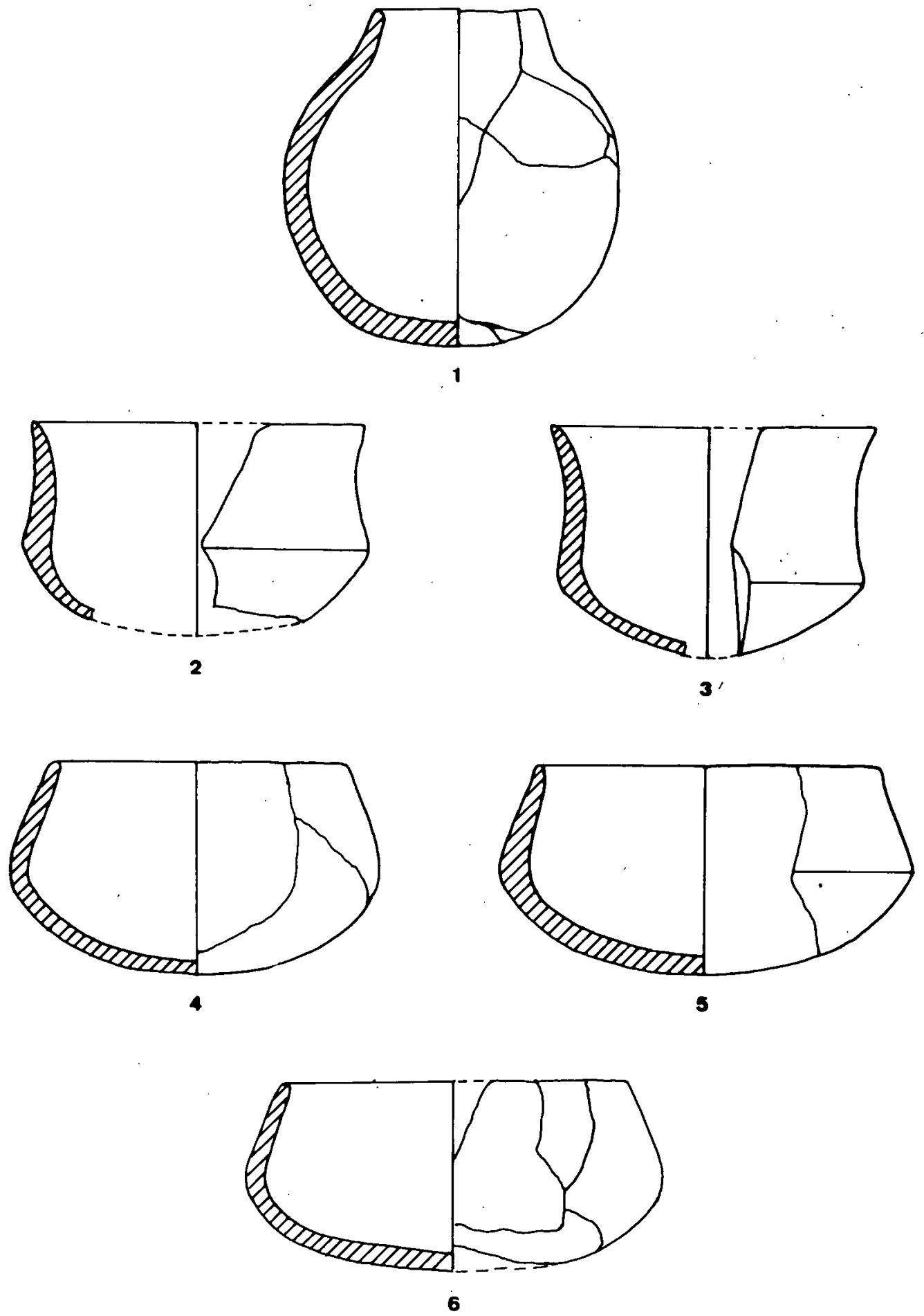

Fig. 8. Recipientes cerámicos de la tumba 3. 

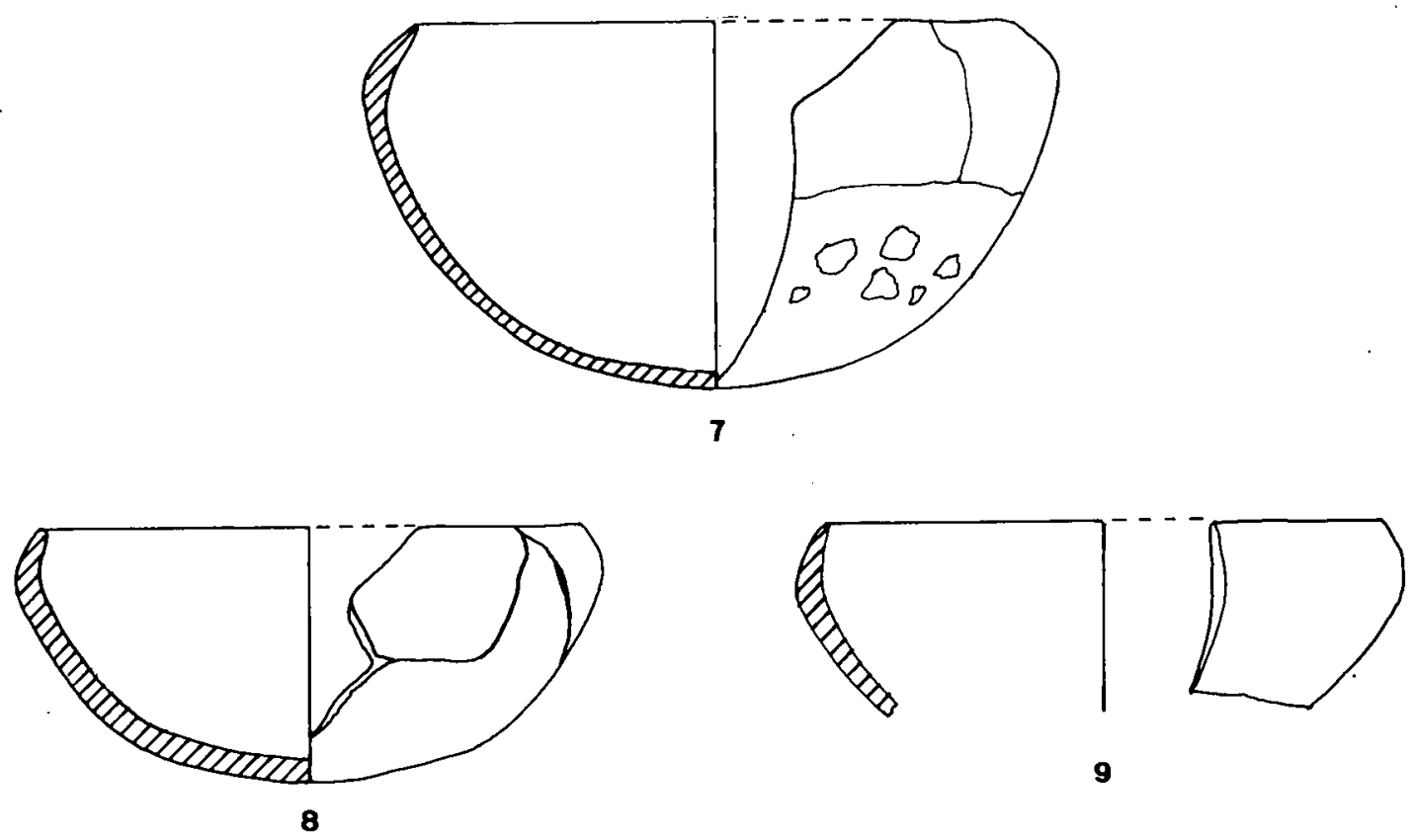

9

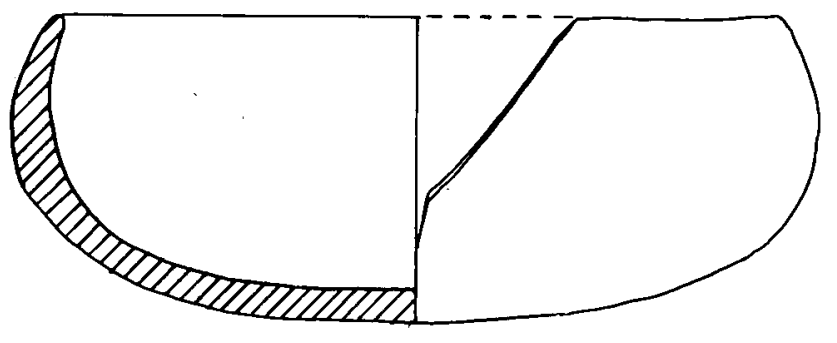

10

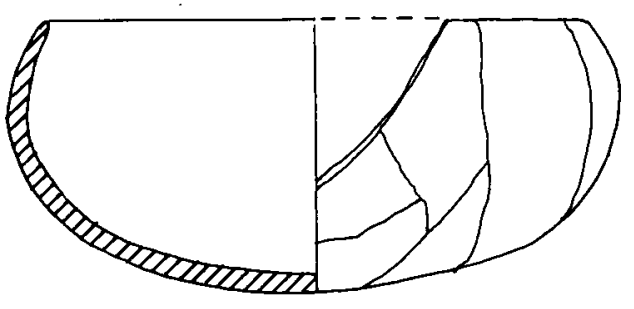

11

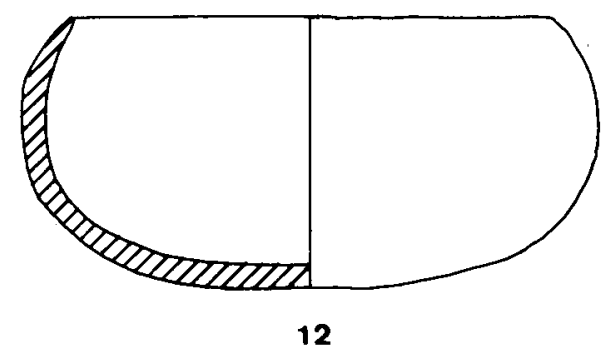

Fig. 9. Recipientes cerámicos de la tumba 3. 

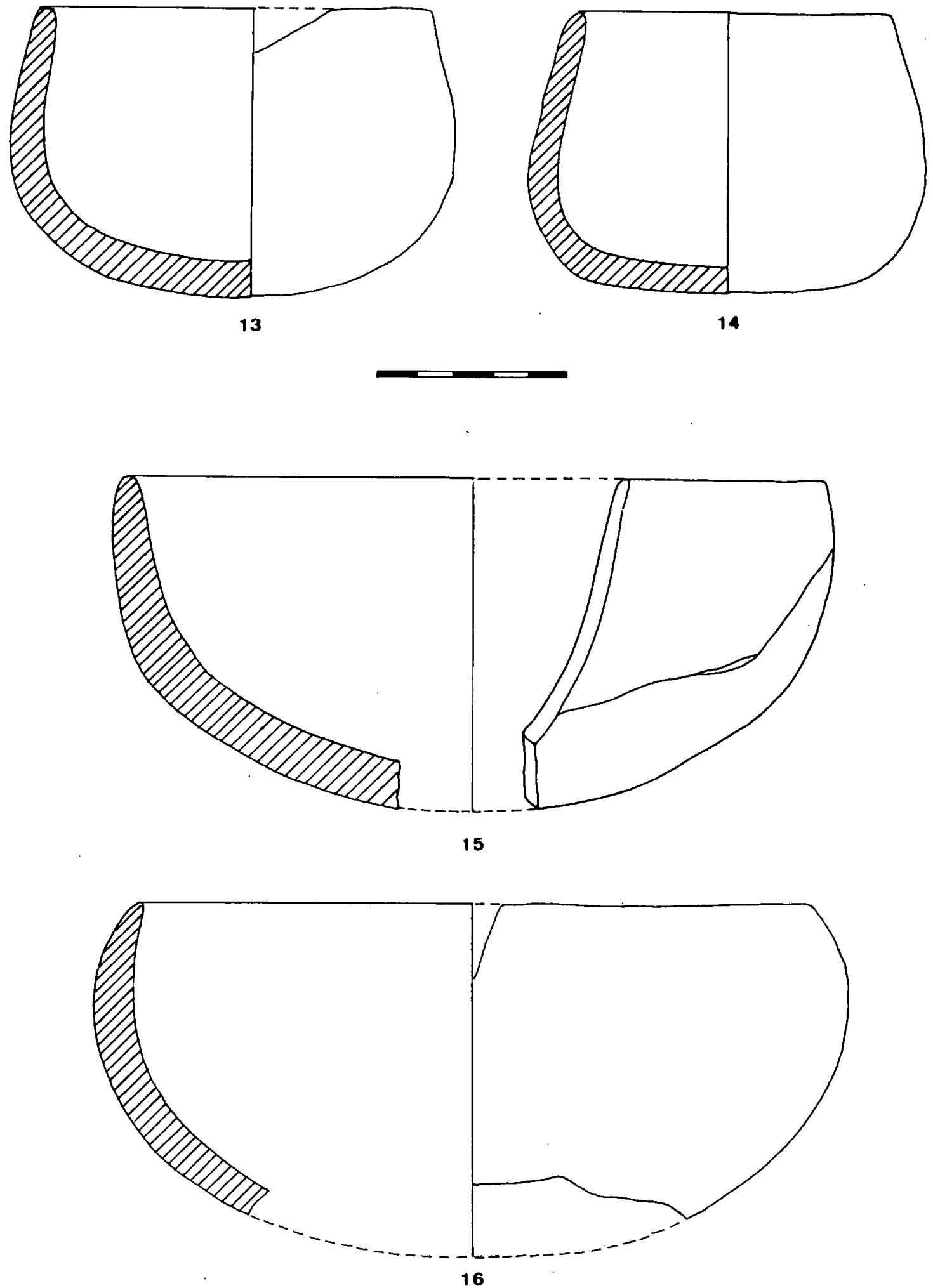

Fig. 10. Recipientes cerámicos de la tumba 3. 

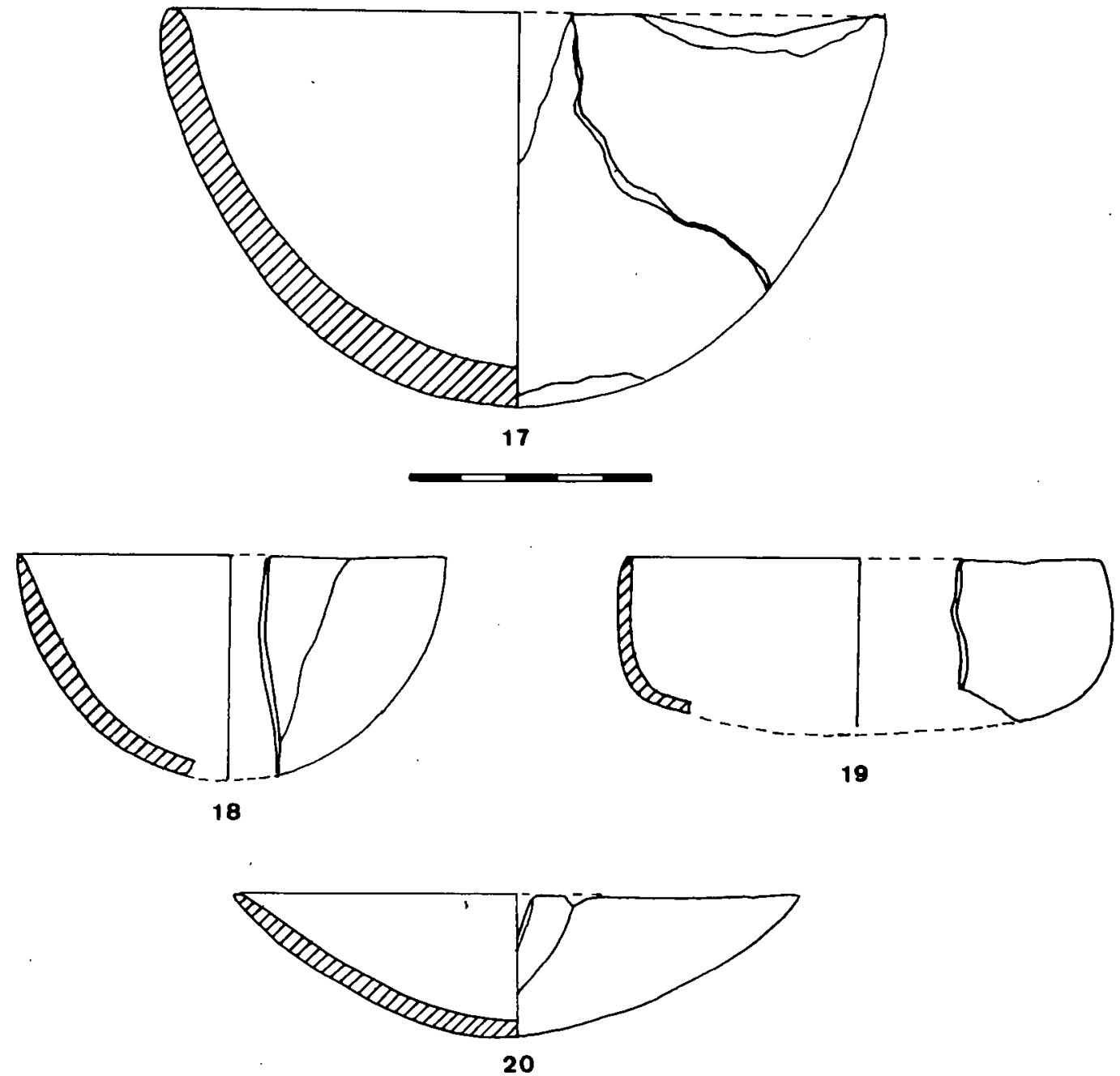

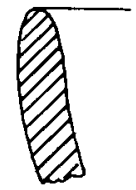

21

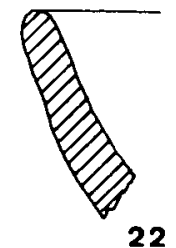

22

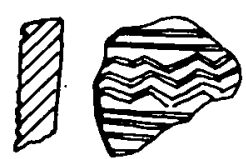

26
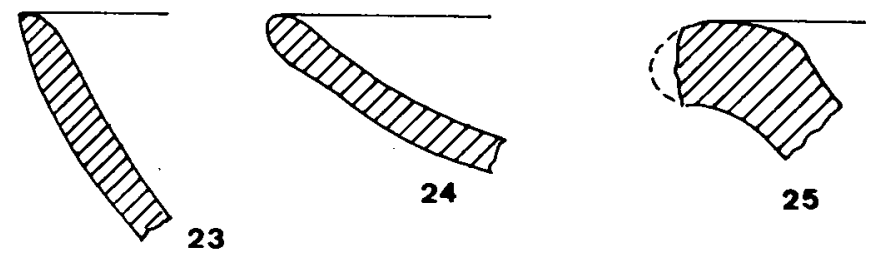

25

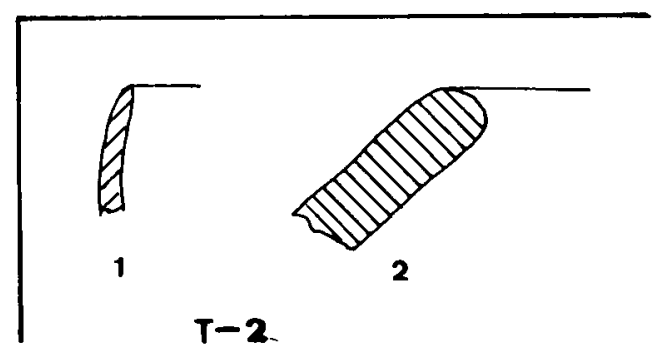

Fig. 11. Recipientes cerámicos de la tumba 3 y de la tumba 1 (n.os 1 y 2). 


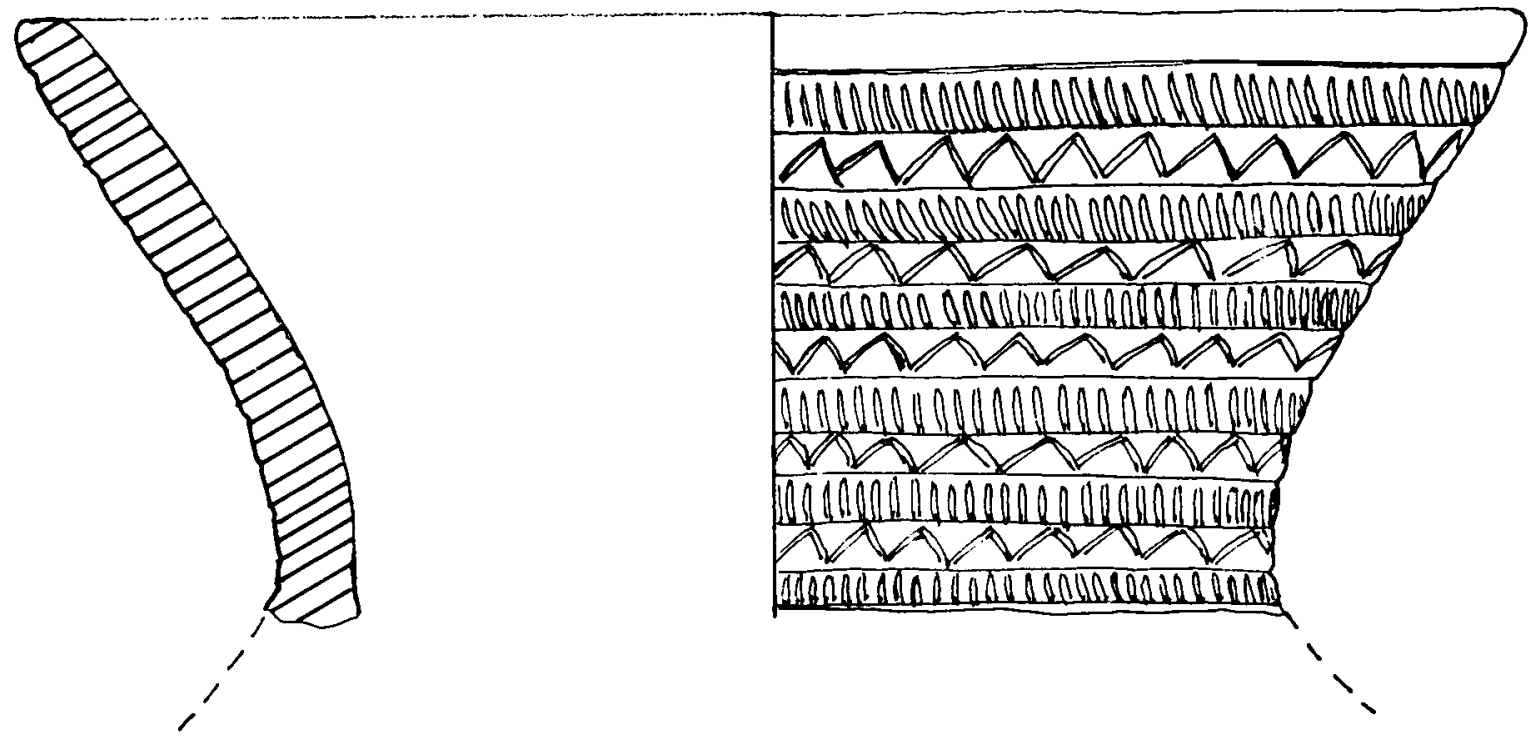

Fig. 12. Cerámica campaniforme de la tumba 3. 


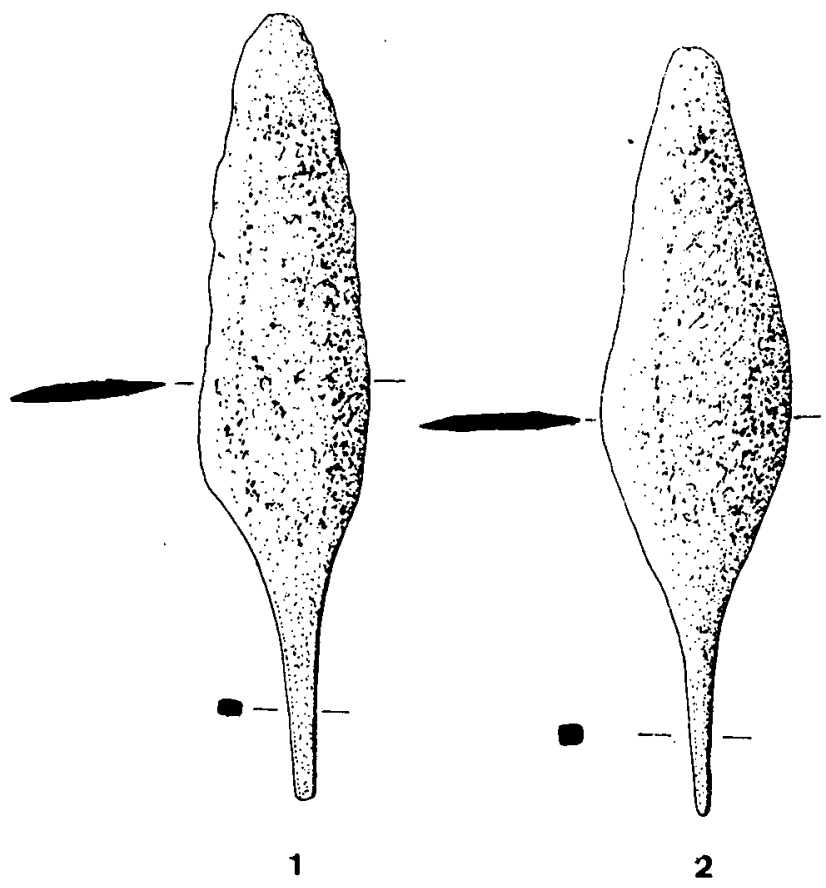

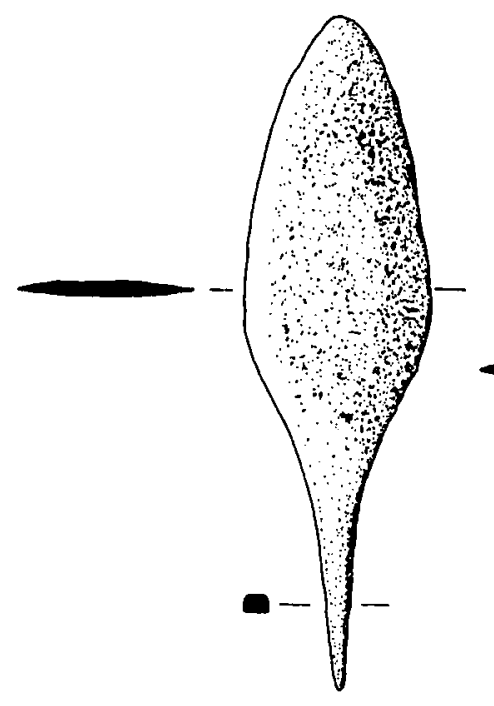

3

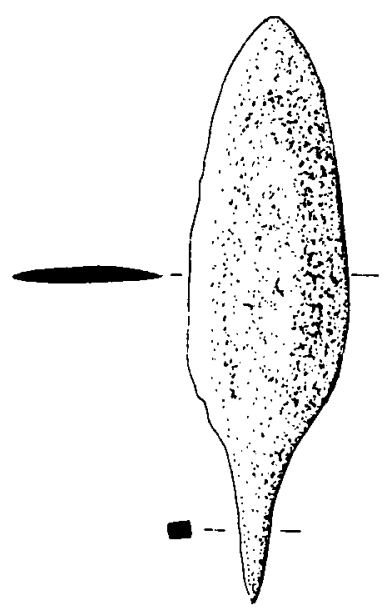

4

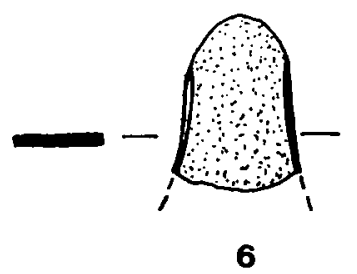

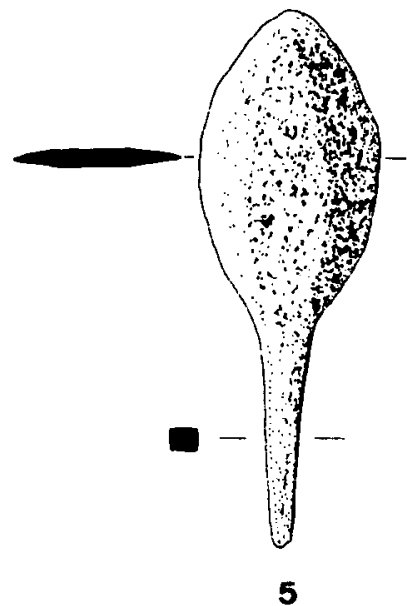

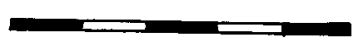

Fig. 13. Puntas de flecha de la tumba 3. 
Necrópolis de Guadajira (Badajoz). Análisis Polínico

\begin{tabular}{|c|c|c|c|c|c|c|}
\hline \multirow[b]{2}{*}{$\overline{\text { Tipos polínicos }}$} & \multicolumn{3}{|c|}{ T. 3/Nivel 3/vaso 14} & \multicolumn{3}{|c|}{ T. 3/Nivel 3/Vaso 9} \\
\hline & $\begin{array}{c}\text { Frecuencia } \\
\text { absoluta } \\
\text { (gr./gramo) }\end{array}$ & $\begin{array}{c}\text { Frecuencia } \\
\text { relativa } \\
\text { (Total) }\end{array}$ & $\begin{array}{l}\text { Frecuencia } \\
\text { relativa } \\
\text { (Grupo) }\end{array}$ & $\begin{array}{c}\text { Frecuencia } \\
\text { absoluta } \\
\text { (gr./gramo) }\end{array}$ & $\begin{array}{c}\text { Frecuencia } \\
\text { relativa } \\
\text { (Total) }\end{array}$ & $\begin{array}{c}\text { Frecuencia } \\
\text { relativa } \\
\text { (Grupo) }\end{array}$ \\
\hline Cupressaceae & 1,57 & $0,30 \%$ & $2,02 \%$ & 0,00 & $0,00 \%$ & $0,00 \%$ \\
\hline Fraxinus & 4,72 & $0,89 \%$ & $6,37 \%$ & 23,08 & $2,00 \%$ & $14,00 \%$ \\
\hline Olea & 0,00 & $0,00 \%$ & $0,00 \%$ & 11,54 & $1,00 \%$ & $7,00 \%$ \\
\hline Pinus & 14,16 & $2,68 \%$ & $19,31 \%$ & 20,20 & $1,75 \%$ & $12,10 \%$ \\
\hline Quercus coccifera & 53,51 & $10,12 \%$ & 72,31 & 106,76 & $9,25 \%$ & $64,60 \%$ \\
\hline Salix & 0,00 & $0,00 \%$ & $0,00 \%$ & 2,88 & $0,25 \%$ & $1,75 \%$ \\
\hline ARBOREOS & 73,96 & $14,00 \%$ & $100,00 \%$ & 164,46 & $14,25 \%$ & $100,00 \%$ \\
\hline Asphodelus Albus & 0,00 & $0,00 \%$ & $0,00 \%$ & 5,77 & $0,50 \%$ & $0,60 \%$ \\
\hline Cardueae & 17,31 & $3,27 \%$ & $4,17 \%$ & 31,74 & $2,75 \%$ & $3,70 \%$ \\
\hline Chenopodium & 3,14 & $0,59 \%$ & $0,75 \%$ & 0,00 & $0,00 \%$ & $0,00 \%$ \\
\hline Centaurea & 0,00 & $0,00 \%$ & $0,00 \%$ & 2,88 & $0,25 \%$ & $0,33 \%$ \\
\hline Cerealia & 0,00 & $0,00 \%$ & $0,00 \%$ & 20,20 & $1,75 \%$ & $2,37 \%$ \\
\hline Cruciferae & 51,94 & $9,82 \%$ & $12,51 \%$ & 118,31 & $10,25 \%$ & $13,90 \%$ \\
\hline Cyperaceae & 0,00 & $0,00 \%$ & $0,00 \%$ & 8,66 & $0,75 \%$ & $1,00 \%$ \\
\hline Erica & 3,15 & $0,59 \%$ & $0,75 \%$ & 11,54 & $1,00 \%$ & $1,30 \%$ \\
\hline Gramineae & 66,10 & $12,50 \%$ & $15,92 \%$ & 86,57 & $7,50 \%$ & $10,10 \%$ \\
\hline Leguminosae & 0,00 & $0,00 \%$ & $0,00 \%$ & 2,88 & $0,25 \%$ & $0,33 \%$ \\
\hline Liguliflorae & 97,58 & $18,45 \%$ & $23,51 \%$ & 236,61 & $20,50 \%$ & $27,80 \%$ \\
\hline Myrtus & 3,15 & $0,59 \%$ & $0,75 \%$ & 20,20 & $1,75 \%$ & $2,37 \%$ \\
\hline Narcissus & 0,00 & $0,00 \%$ & $0,00 \%$ & 2,88 & $0,25 \%$ & $0,33 \%$ \\
\hline Paronychia & 61,38 & $11,60 \%$ & $14,75 \%$ & 118,31 & $10,25 \%$ & $13,90 \%$ \\
\hline Plantago & 4,72 & $0,89 \%$ & $1,13 \%$ & 2,88 & $0,25 \%$ & $0,33 \%$ \\
\hline Tubiflorae & 105,45 & $19,94 \%$ & $25,40 \%$ & 178,90 & $15,50 \%$ & $21,00 \%$ \\
\hline Umbelliferae & 1,57 & $0,30 \%$ & $0,37 \%$ & 2,88 & $0,25 \%$ & $0,33 \%$ \\
\hline \multicolumn{7}{|l|}{ ARBUSTIVOS\% } \\
\hline HERBACEOS & 415,49 & $78,54 \%$ & $10,00 \%$ & 851,21 & $73,50 \%$ & $100, .00 \%$ \\
\hline Isoetes & 0,00 & $0,00 \%$ & & 2,88 & $0,25 \%$ & \\
\hline Triletas & 1,57 & $0,30 \%$ & & 0,00 & $0,00 \%$ & \\
\hline No identificados & 37,77 & $7,14 \%$ & & 135,60 & $11,75 \%$ & \\
\hline TOTAL & 491,02 & $100,00 \%$ & & 1018,47 & $100,00 \%$ & \\
\hline
\end{tabular}

Fig. 14. Análisis paleopolínico del sedimento del Vaso 9 de la tumba 3. Distribución de tipos polínicos. 
Estadística descriptiva

Atura máxima y diámetro máximo

\begin{tabular}{lcc}
\hline Variable & Altura & Diámetro \\
\hline Tamaño muestra & 56 & 56 \\
Media & 5,29 & 9,50 \\
Mediana & 5,05 & 9,15 \\
Moda & 5,40 & 8,60 \\
Media geométrica & 5,08 & 9,36 \\
Varianza & 2,63 & 4,45 \\
Desviación estándar & 1,62 & 2,11 \\
Mínimo & 2,60 & 5,40 \\
Máximo & 11,70 & 17,20 \\
Rango & 9,10 & 11,80 \\
Cuartil inferior & 4,40 & 8,30 \\
Cuartil superior & 5,60 & 9,95 \\
Rango intercuartil & 1,20 & 1,65 \\
Desviación & 1,60 & 1,32 \\
Desviación estandarizada & 4,91 & 4,04 \\
Curtosis & 3,94 & 2,77 \\
Curtosis estandarizada & 6,02 & 4,23
\end{tabular}

Dimensiones máximas medias. Cuadro comparativo

\begin{tabular}{lccc}
\hline Muestra & $\begin{array}{r}\text { Tamaño } \\
\text { muestra }\end{array}$ & $\begin{array}{c}\text { Altura } \\
\text { muestra }\end{array}$ & $\begin{array}{c}\text { Diámetro } \\
\text { máximo }\end{array}$ \\
\hline $\begin{array}{l}\text { Sierra Norte de Huelva } \\
\text { (c. 2500-1700 a.n.e.) }\end{array}$ & 63 & $7,2 \mathrm{~cm}$. & $13,5 \mathrm{~cm}$ \\
$\begin{array}{l}\text { Sierra Norte de Huelva } \\
\text { (c. 1700-1100 a.n.e.) }\end{array}$ & 117 & $7,5 \mathrm{~cm}$. & $13,1 \mathrm{~cm}$. \\
$\begin{array}{l}\text { Suroeste peninsular } \\
\text { (c. 1700-1100 a.n.e.) }\end{array}$ & 125 & $7,5 \mathrm{~cm}$. & $12,6 \mathrm{~cm}$. \\
Necropolis de Guadajira & 56 & $5,2 \mathrm{~cm}$. & $9,5 \mathrm{~cm}$.
\end{tabular}

Coeficiente de variabilidad. Cuadro comparativo

\begin{tabular}{lcc}
\hline & Altura máxima & Diámetro máximo \\
\hline Suroeste peninsular & 55.2 & 28,9 \\
Sierra norte de Huelva & 49,4 & 26,0 \\
Necrópolis de Guadajira & 30,6 & 22,2 \\
Tumba 3 de Guadajira & 26,4 & 22,3 \\
Tumba 1 de Guadajira & 29,8 & 17,2
\end{tabular}

Fig. 15. Análisis morfométrico de los recipientes cerámicos (I). Estadística descriptiva de las variables altura máxima y diámetro máximo. 
Tabla de frecuencias Altura máxima

\begin{tabular}{cccccccc}
\hline Clase & $\begin{array}{c}\text { Límite } \\
\text { Inferior }\end{array}$ & $\begin{array}{c}\text { Límite } \\
\text { Superior }\end{array}$ & $\begin{array}{c}\text { Punto } \\
\text { Medio }\end{array}$ & $\begin{array}{c}\text { Frecuencia } \\
\text { Absoluta }\end{array}$ & $\begin{array}{c}\text { Frecuencia } \\
\text { Relativa }\end{array}$ & $\begin{array}{c}\text { Frec. Ab. } \\
\text { Acumulada }\end{array}$ & $\begin{array}{c}\text { Frec. Rel. } \\
\text { Acumulada }\end{array}$ \\
\hline & & .00 & & 0 & .0000 & 0 & .000 \\
1 & .00 & 2.00 & 1.00 & 0 & .0000 & 0 & .000 \\
2 & 2.00 & 4.00 & 3.00 & 12 & .2143 & 12 & .214 \\
3 & 4.00 & 6.00 & 5.00 & 34 & .6071 & 46 & .821 \\
4 & 6.00 & 8.00 & 7.00 & 6 & .1071 & 52 & .929 \\
5 & 8.00 & 10.00 & 9.00 & 3 & .0536 & 55 & .982 \\
6 & 10.00 & 12.00 & 11.00 & 1 & .0179 & 56 & 1.000 \\
7 & 12.00 & 14.00 & 13.00 & 0 & .0000 & 56 & 1.000 \\
& $<$ & 14.00 & & 0 & .0000 & 56 & 1.000 \\
\hline
\end{tabular}

Tabla de frecuencias

Diámetro máximo

\begin{tabular}{lccccccc}
\hline Clase & $\begin{array}{c}\text { Limite } \\
\text { Inferior }\end{array}$ & $\begin{array}{c}\text { Limite } \\
\text { Superior }\end{array}$ & $\begin{array}{c}\text { Punto } \\
\text { Medio }\end{array}$ & $\begin{array}{c}\text { Frecuencia } \\
\text { Absoluta }\end{array}$ & $\begin{array}{c}\text { Frecuencia } \\
\text { Relativa }\end{array}$ & $\begin{array}{c}\text { Frec. Ab. } \\
\text { Acumulada }\end{array}$ & $\begin{array}{c}\text { Frec. Rel. } \\
\text { Acumulada }\end{array}$ \\
\hline & & .00 & & 0 & .0000 & 0 & .0000 \\
1 & .00 & 2.00 & 1.00 & 0 & .0000 & 0 & .0000 \\
2 & 2.00 & 4.00 & 3.00 & 0 & .0000 & 0 & .0000 \\
3 & 4.00 & 6.00 & 5.00 & 1 & .0179 & 1 & .0179 \\
4 & 6.00 & 8.00 & 7.00 & 10 & .1786 & 11 & .1964 \\
5 & 8.00 & 10.00 & 9.00 & 32 & .5714 & 43 & .7679 \\
6 & 10.00 & 12.00 & 11.00 & 6 & .1071 & 49 & .8750 \\
7 & 12.00 & 14.00 & 13.00 & 4 & .0714 & 53 & .9464 \\
8 & 14.00 & 16.00 & 15.00 & 2 & .0357 & 55 & .9821 \\
9 & 16.00 & 18.00 & 17.00 & 1 & .0179 & 56 & 1.0000 \\
& $<$ & 18.00 & & 0 & .0000 & 56 & 1.0000 \\
\hline
\end{tabular}

Mean $=9.57321 \quad$ Standard Deviation $=2.11131$

Median $=9.15$

Fig. 16. Análisis morfométrico de los recipientes cerámicos (II). Tabla de frecuencias de intervalos de las variables altura máxima y diámetro máximo. 

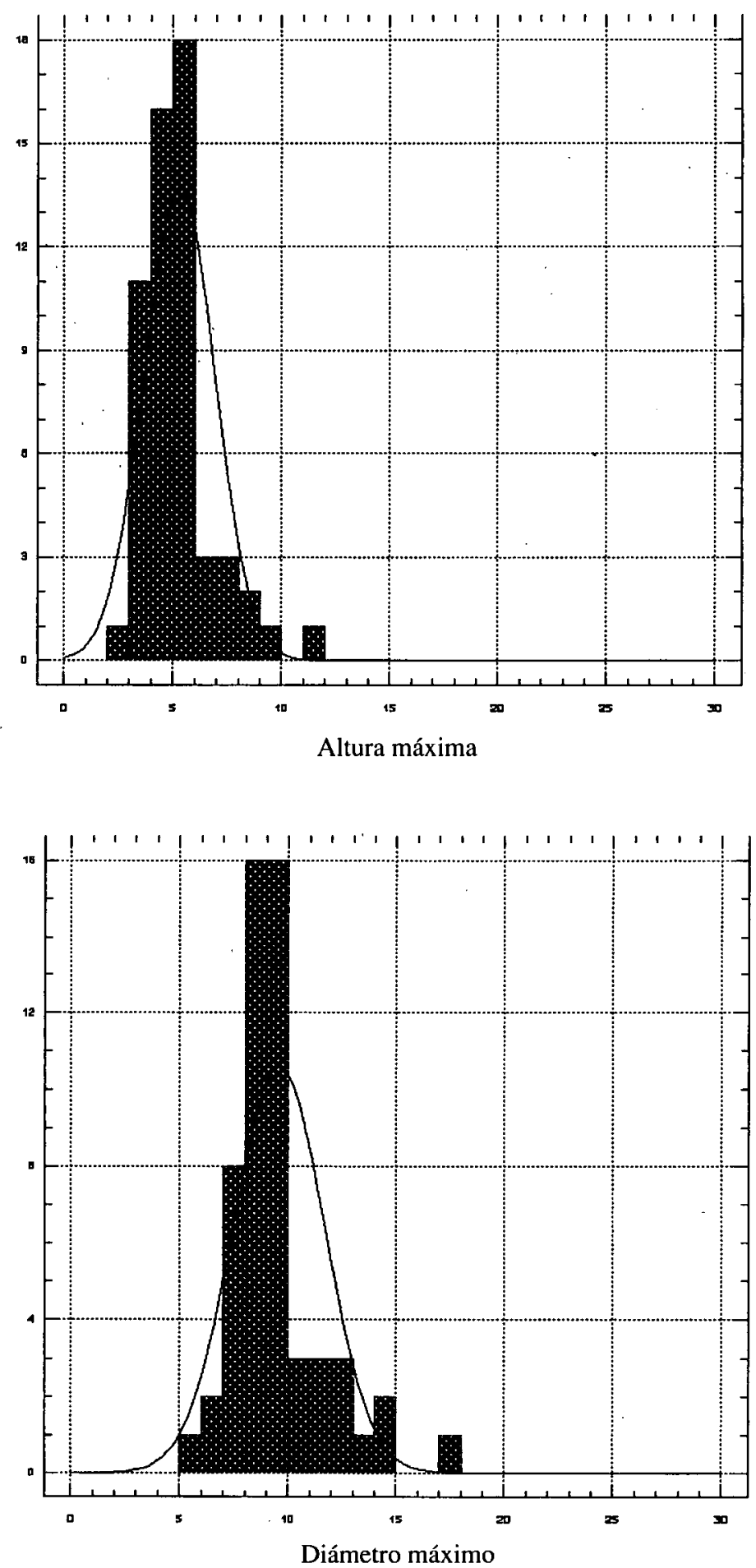

Fig. 17. Análisis morfométrico de los recipientes cerámicos (III). Histogramas de frecuencia de las variables altura máxima y diámetro máximo. 

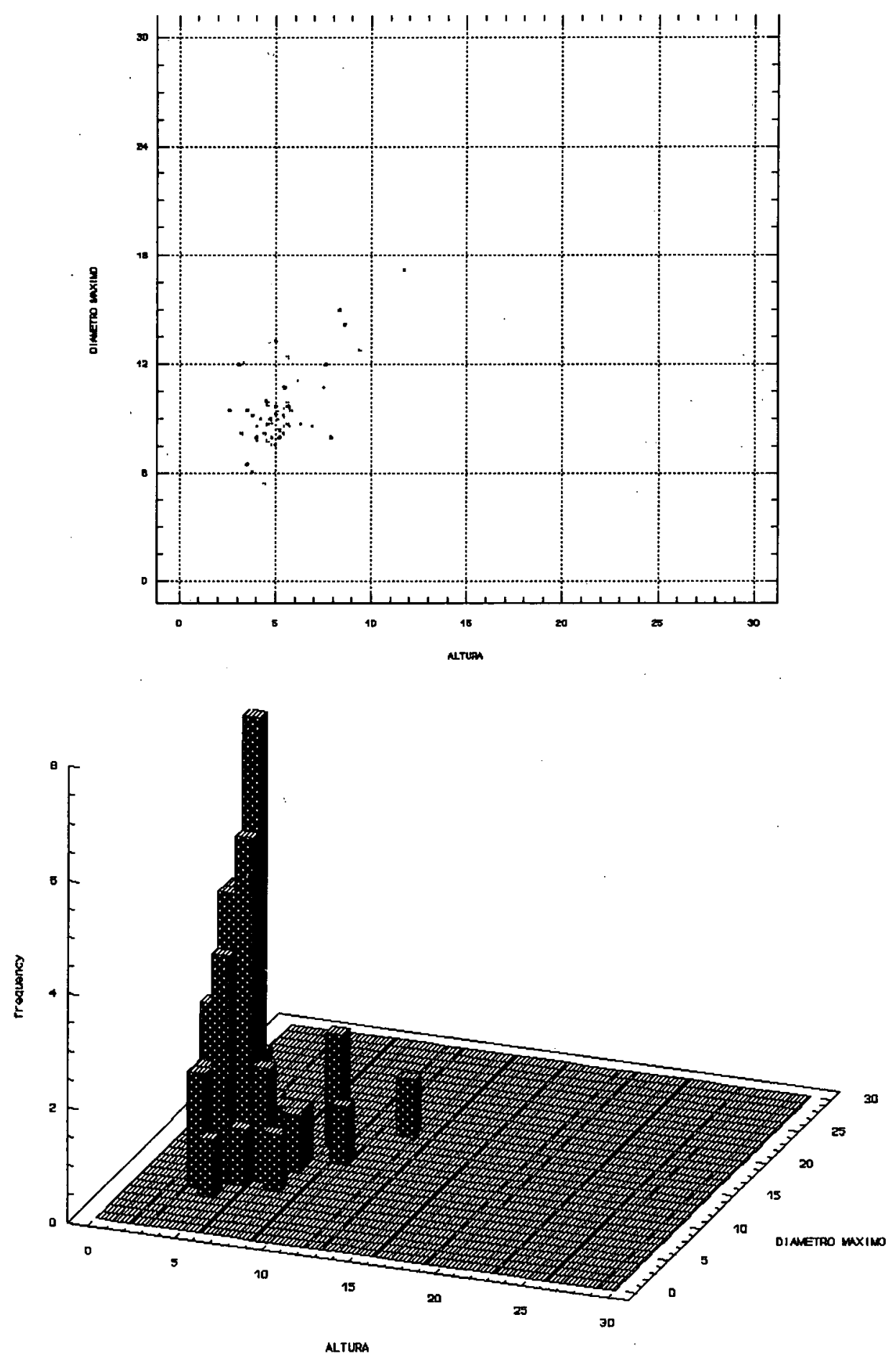

Fig. 18. Análisis morfométrico de los recipientes cerámicos (IV). Distribución combinada de las variables altura máxima y diámetro máximo. 


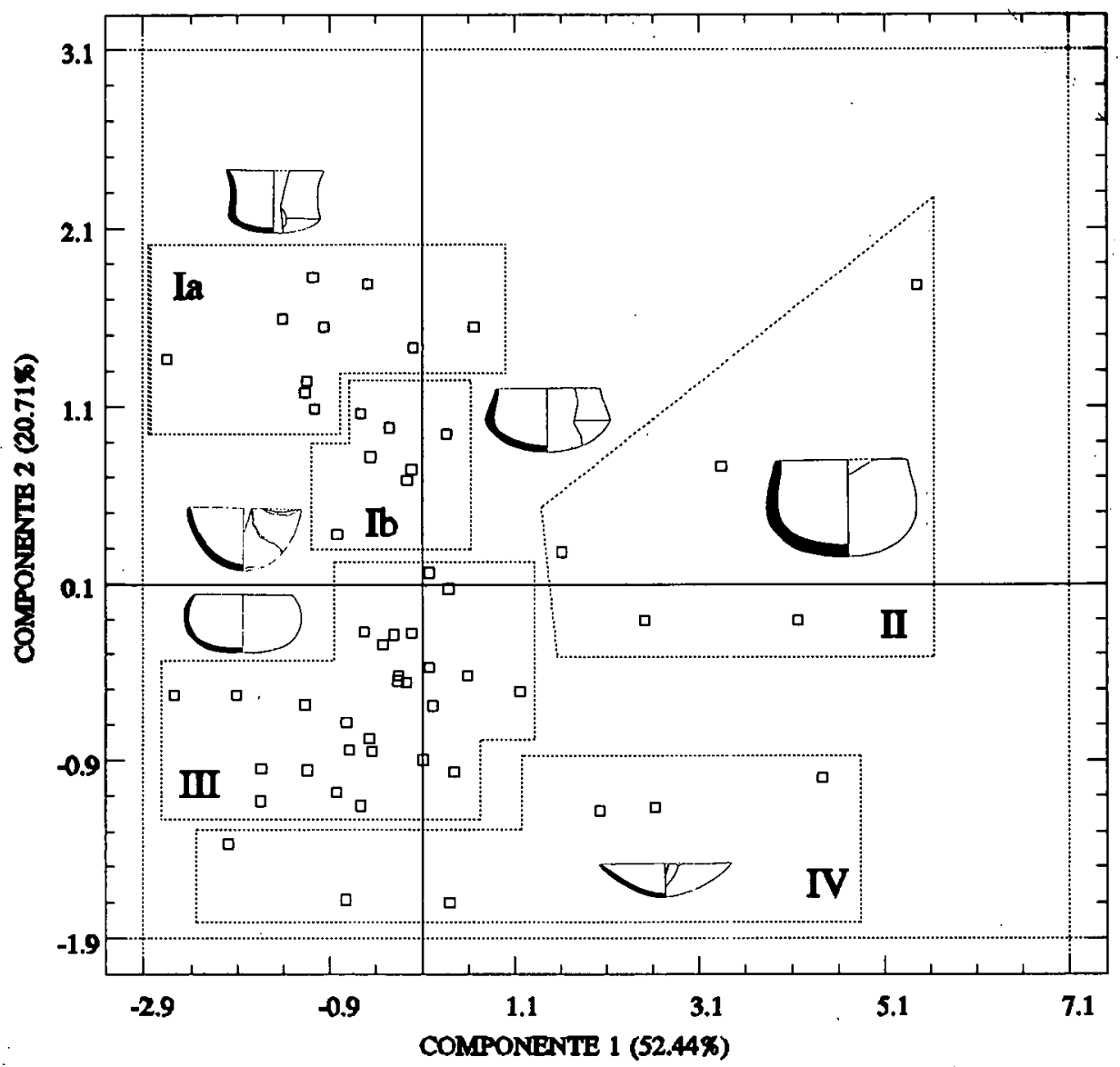

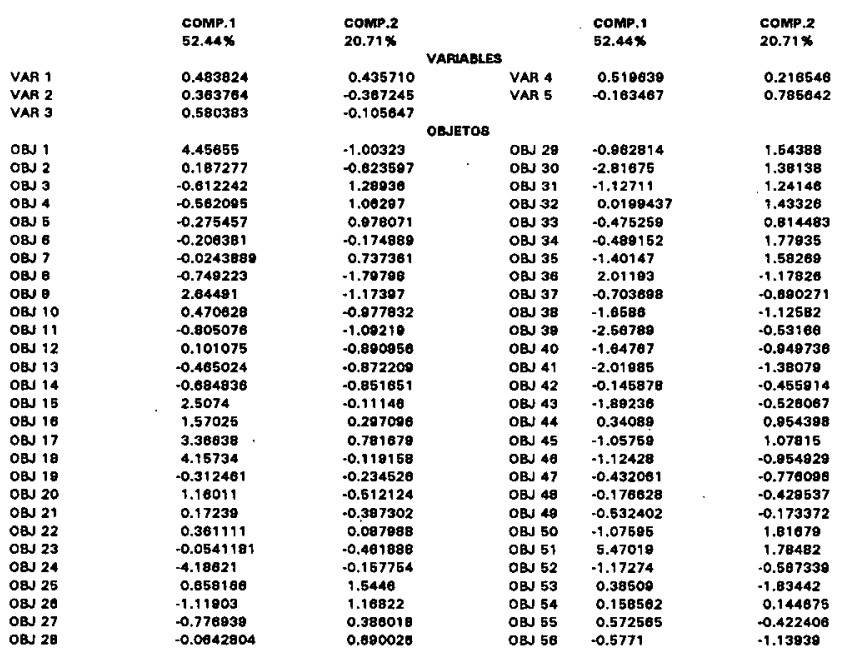

Fig. 19. Análisis morfométrico de los recipientes cerámicos (V). Análisis de componentes principales. 


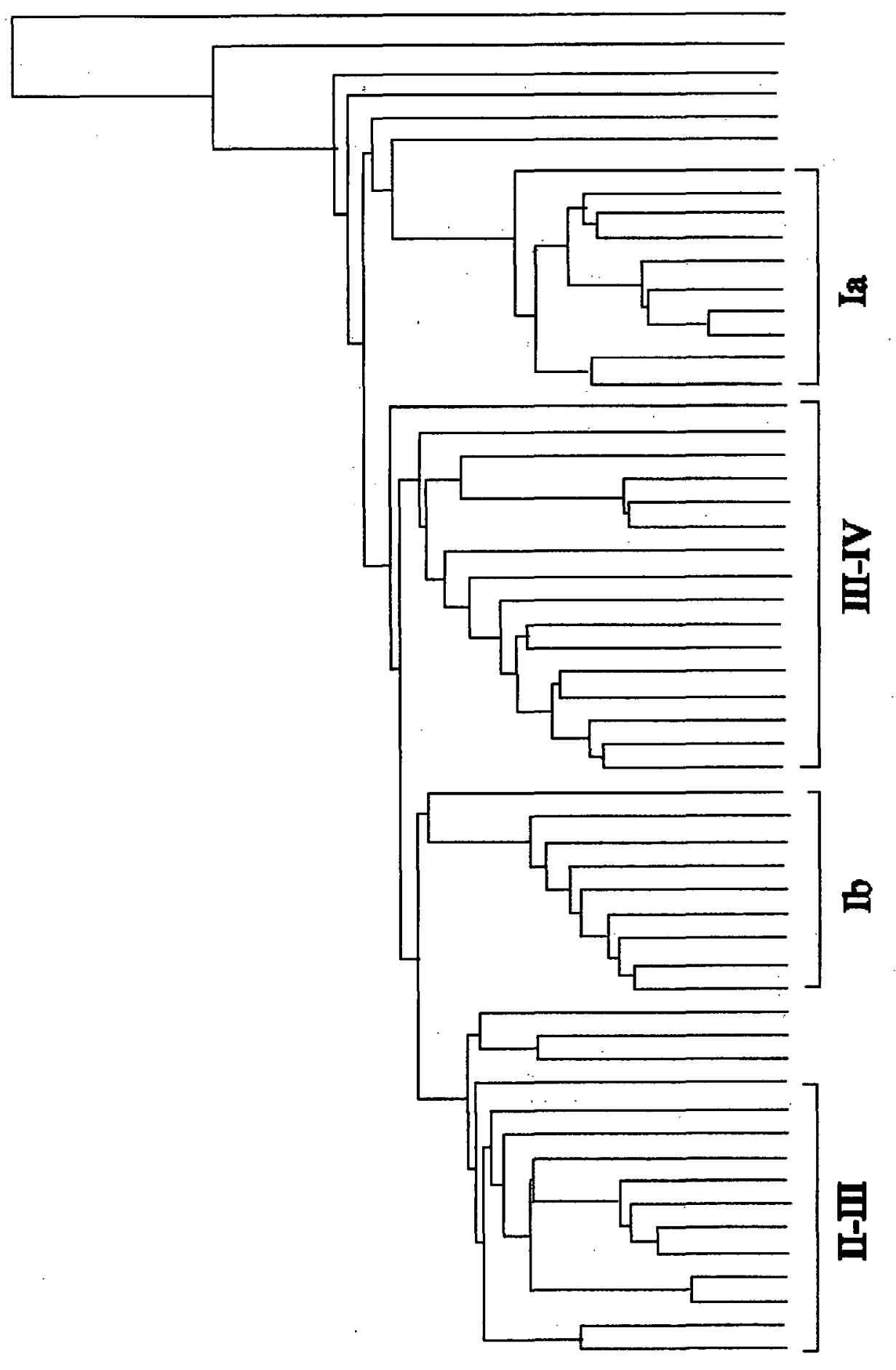




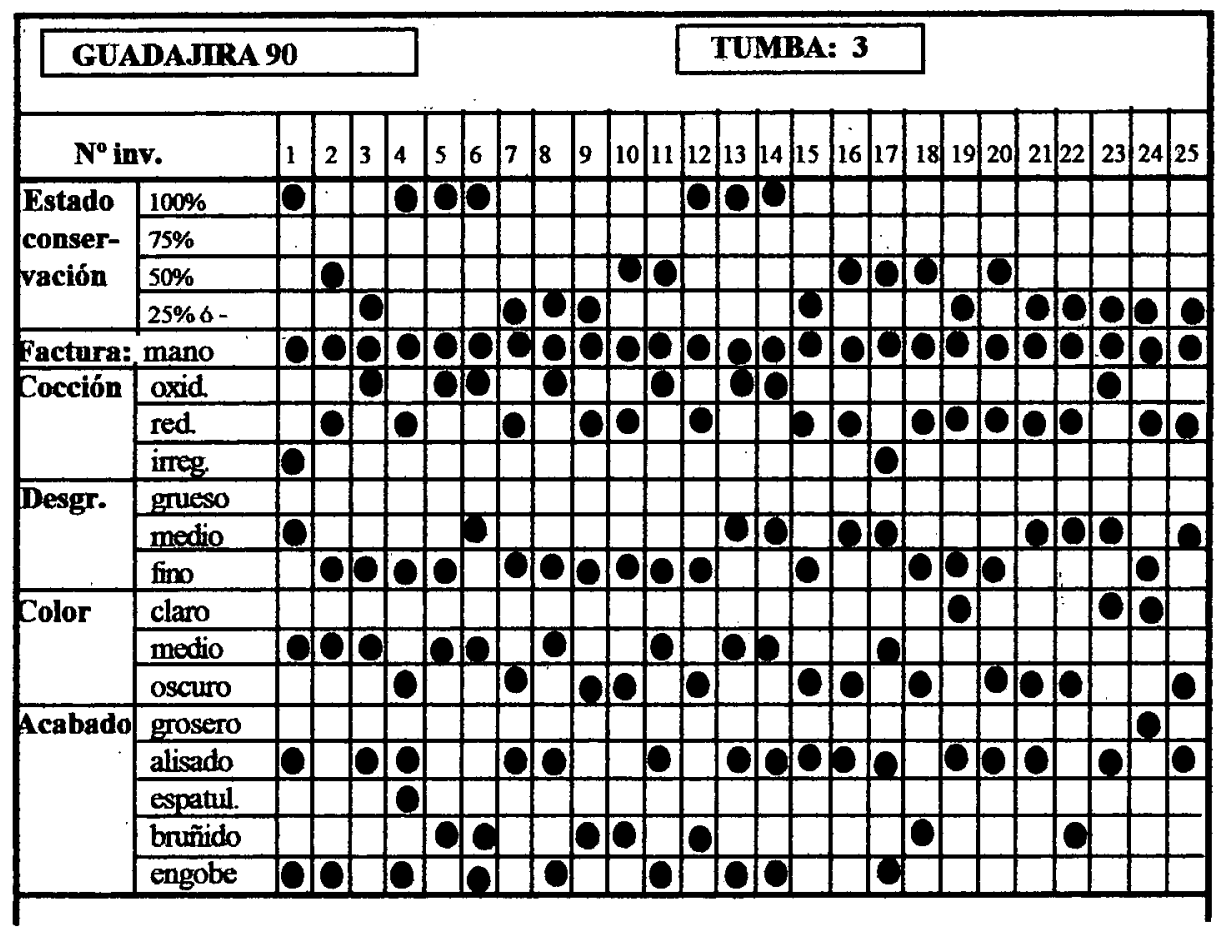

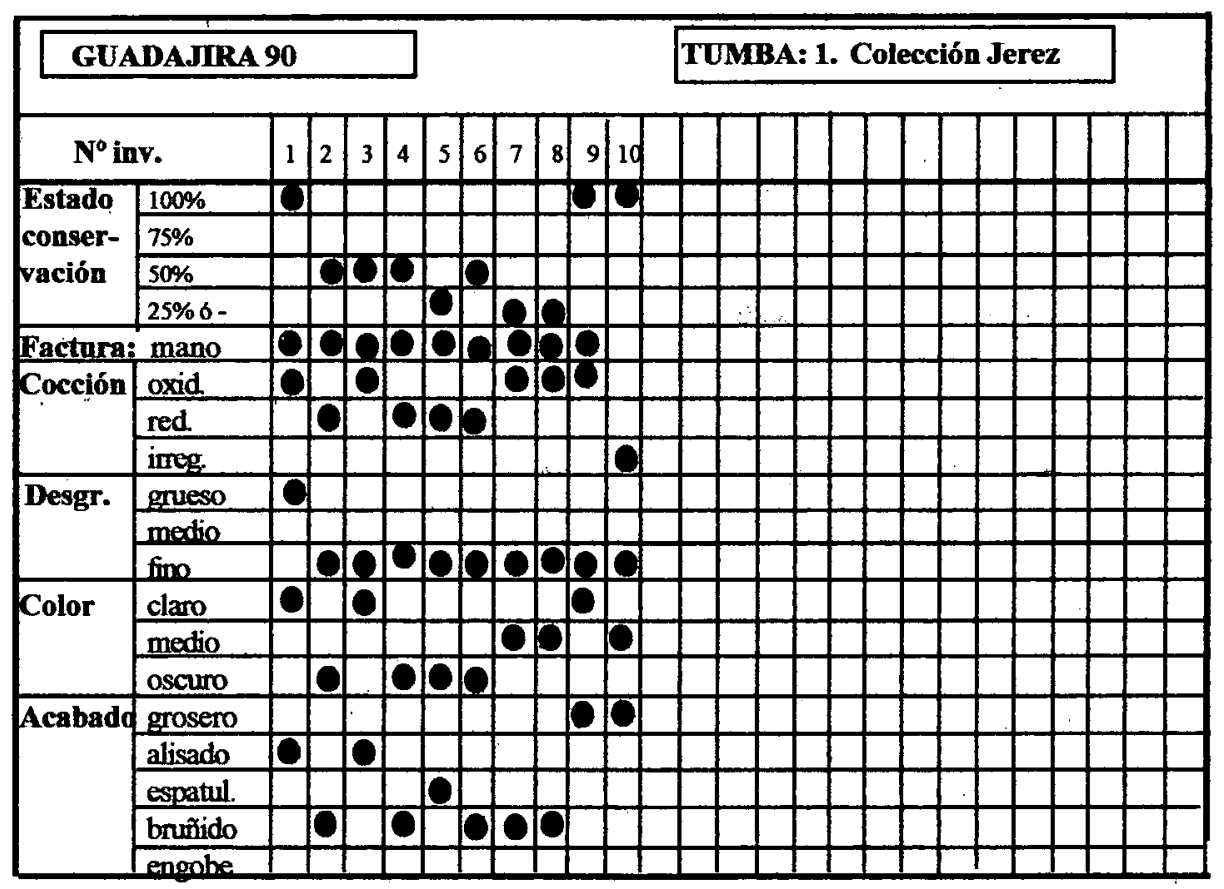

Fig. 21. Análisis tecnológico de los recipientes cerámicos. Tablas de datos. 


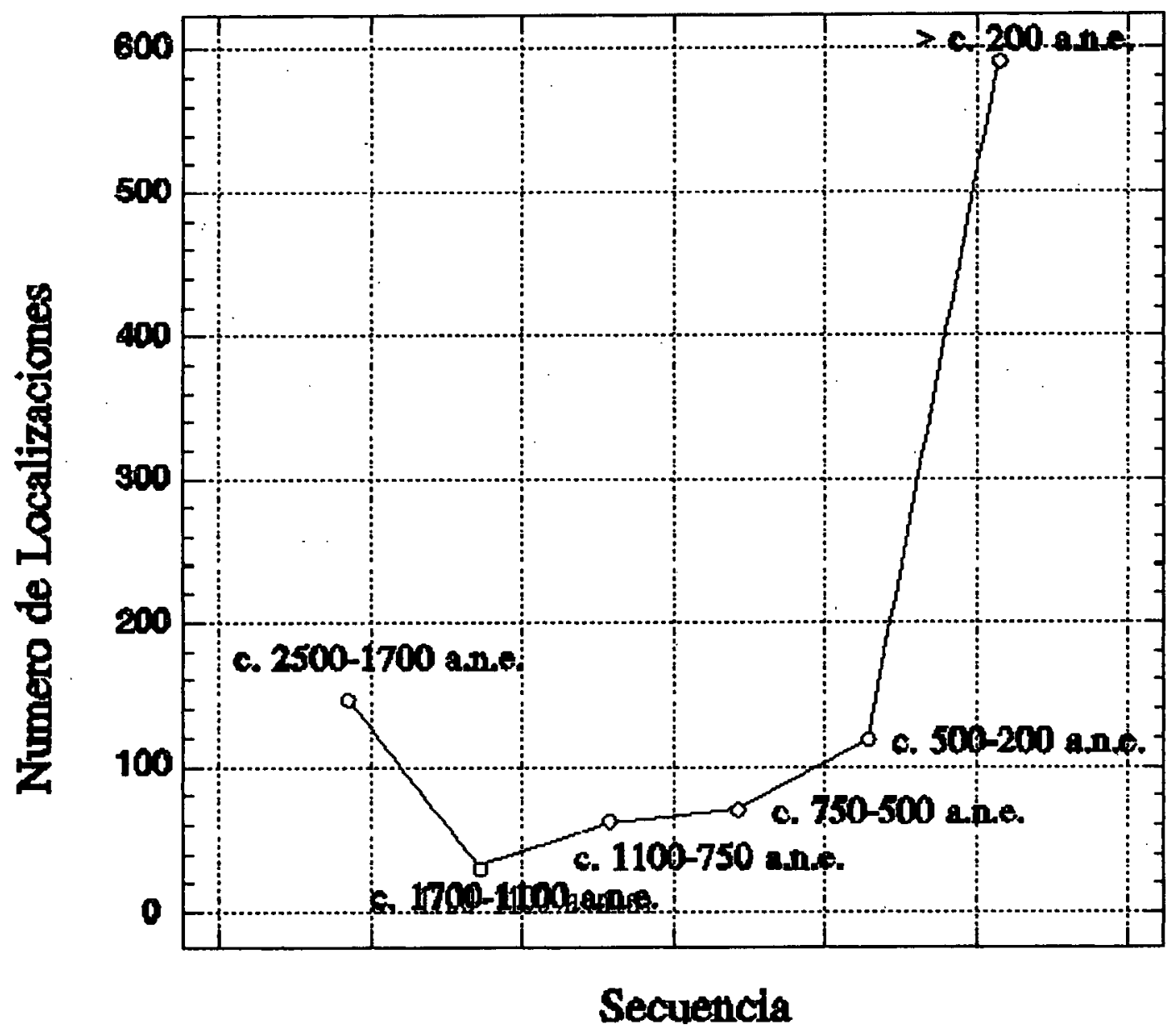

Fig. 22. Localizaciones arqueológicas en la Prehistoria reciente del Suroeste. 


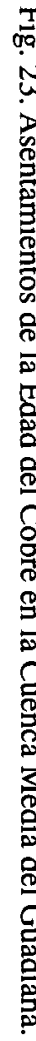

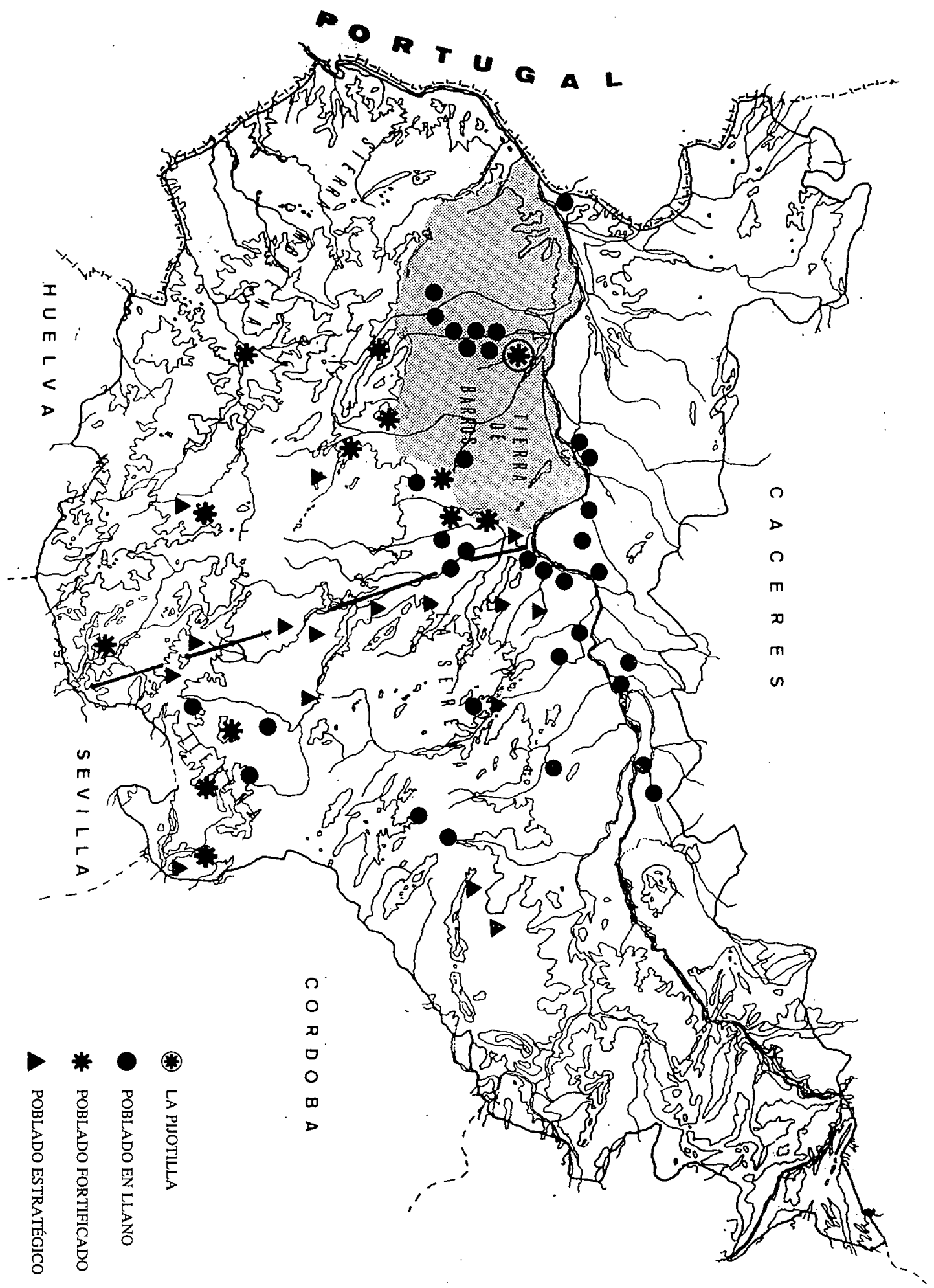




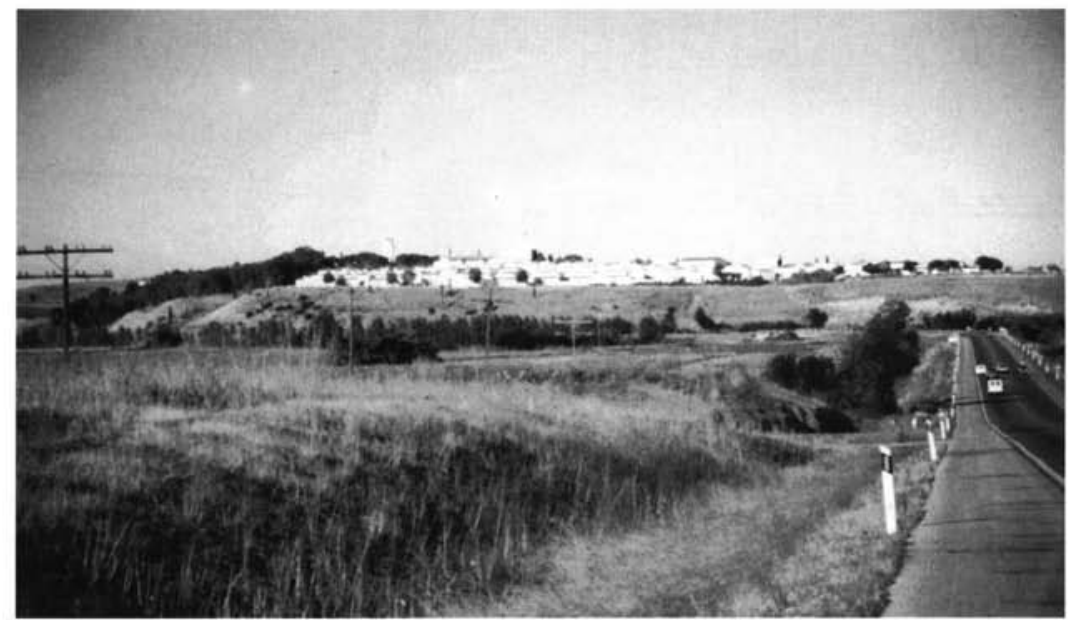

Lámina L. Ubicación del yacimiento de Guadajira.

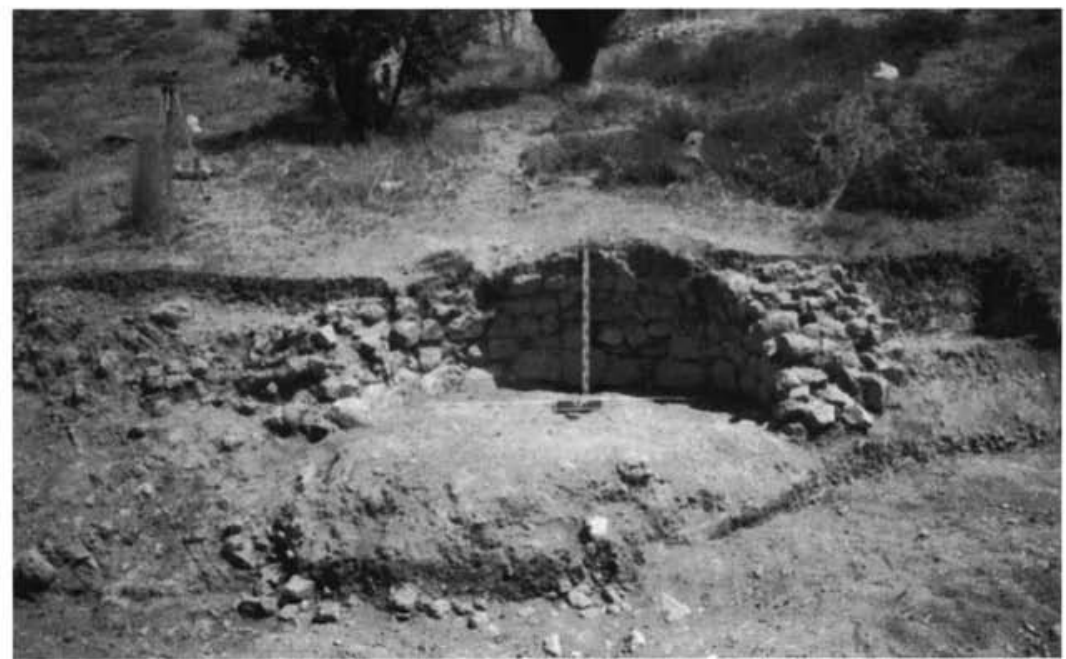

Lámina II. Tumba 2. 


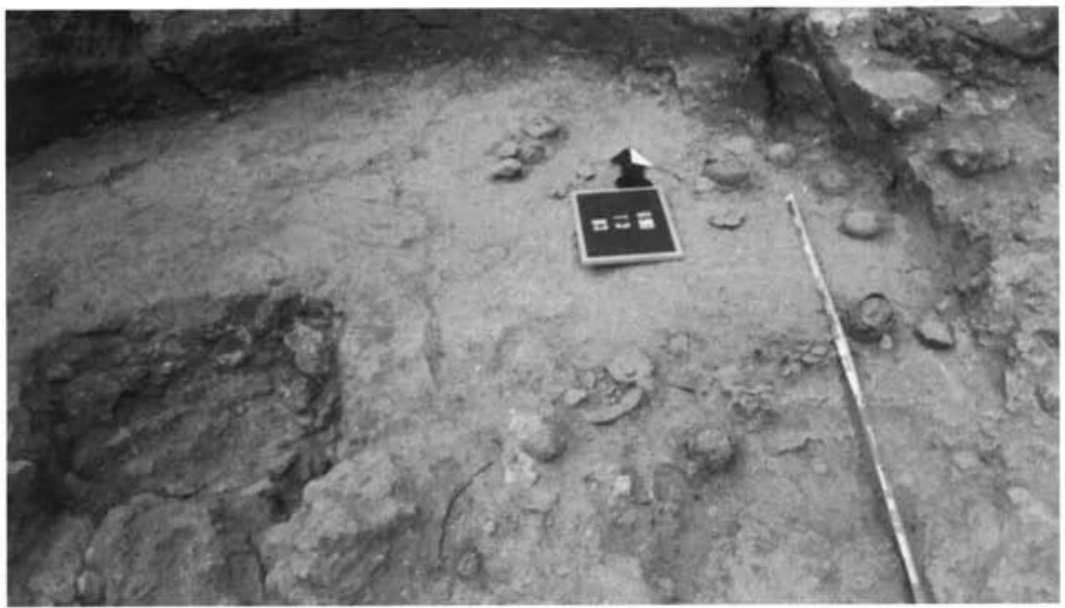

Lámina III. Tumba 3.

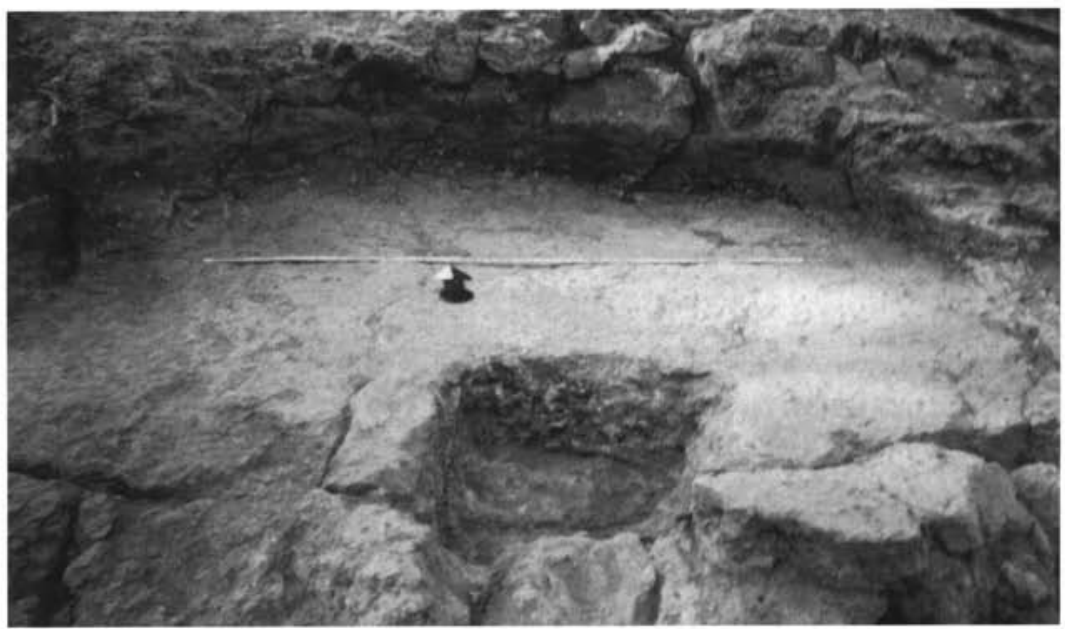

Lámina IV. Tumba 3. 